\title{
Alleviation of Salt Stress by Plant Growth-Promoting Bacteria in Hydroponic Leaf Lettuce
}

\author{
Alessandra Moncada ${ }^{\mathbb{D}}$, Filippo Vetrano * and Alessandro Miceli *(D) \\ Department of Agricultural, Food and Forestry Sciences, University of Palermo, Viale delle Scienze 4, \\ 90128 Palermo, Italy; alessandra.moncada@unipa.it \\ * Correspondence: filippo.vetrano@unipa.it (F.V.); alessandro.miceli@unipa.it (A.M.); \\ Tel.: +39-091-23862229 (F.V.); +39-091-23862219 (A.M.)
}

Received: 10 September 2020; Accepted: 2 October 2020; Published: 6 October 2020

\begin{abstract}
Mediterranean areas with intensive agriculture are characterized by high salinity of groundwater. The use of this water in hydroponic cultivations can lead to nutrient solutions with an electrical conductivity that overcomes the tolerance threshold of many vegetable species. Plant growth-promoting rhizobacteria (PGPR) were shown to minimize salt stress on several vegetable crops but the studies on the application of PGPR on leafy vegetables grown in hydroponics are rather limited and have not been used under salt stress conditions. This study aimed to evaluate the use of plant growth-promoting bacteria to increase the salt tolerance of leaf lettuce grown in autumn and spring in a floating system, by adding a bacterial biostimulant $\left(1.5 \mathrm{~g} \mathrm{~L}^{-1}\right.$ of TNC Bactorr ${ }^{\mathrm{S} 13} \mathrm{a}$ commercial biostimulant containing $1.3 \times 10^{8} \mathrm{CFU} \mathrm{g}^{-1}$ of Bacillus spp.) to mineral nutrient solutions (MNS) with two salinity levels ( 0 and $20 \mathrm{mM} \mathrm{NaCl}$ ). Leaf lettuce plants showed a significant reduction of growth and yield under salt stress, determined by the reduction of biomass, leaf number, and leaf area. Plants showed to be more tolerant to salinity in autumn than in spring. The inhibition of lettuce plant growth due to salt stress was significantly alleviated by the addition of the bacterial biostimulant to the MNS, which had a positive effect on plant growth and fresh and dry biomass accumulation of the unstressed lettuce in both cultivation seasons, and maintained this positive effect in brackish MNS, with similar or even significantly higher values of morphologic, physiologic, and yield parameters than those recorded in control unstressed plants.
\end{abstract}

Keywords: saline water; leafy vegetables; Lactuca sativa L. var. Crispa; floating system; nutrient solution; bacterial biostimulant; PGPR; Bacillus

\section{Introduction}

The need to attend the increasing food demand while protecting the environment and reducing the use of natural resources led to the search for more sustainable agriculture [1]. This major challenge of agricultural research is hindered by the rapid growth of the human population and the decreasing availability of natural resources and land for cultivation [2]. The increasing degradation of agricultural land and water supplies is linked to the adoption of intensive agricultural practices that can negatively affect the suitability of these natural resources. The accumulation of soluble salts in soils or groundwater is the major factor responsible for the loss of productivity of cultivated soils [3], and represents one of the major environmental stresses for vegetable crops [3,4]. Vegetables are crucial in the human diet, thanks to their high nutritional value, due to their content in vitamins, carbohydrates, proteins, and mineral nutrients [2]. All vegetable crops can be influenced more or less severely by salinity [5], which can limit crop development and yield through modifications of morphology and physiological functions [2]. Salt stress affects vegetable growth due to the osmotic or water-deficit effect, toxic accumulation of salts in shoots, nutritional imbalances, or a combination of these factors [6,7]. 
To minimize the impact of salt stress on vegetable crops, more rational use of land and water resources could be adopted [4]. This might allow vegetable production under salt stress but cannot assure additional gains [8]. Another strategy that could allow overcoming salt stress and other abiotic and biotic stresses [9-11], and to increase yield and improve quality [10,12-15] for many vegetable crops, is the adoption of hydroponic cultivation systems. In these cultivation systems, plants are fed through a mineral nutrient solution and held by mineral or organic materials that anchor the roots, or by panels that host them and float on the nutrient solution (floating system). The water used to prepare nutrient solutions must have good quality characteristics, especially with regards to low salt concentration, as it can influence the electrical conductivity (EC) of the nutrient solution, once water-soluble mineral fertilizers are added to the water [16]. Mediterranean areas with intensive agriculture are characterized by high salinity of groundwater, as the considerable use of irrigation water increases seawater infiltration [17]. The use of this water in hydroponic cultivations can lead to nutrient solutions with an EC that overcomes the tolerance threshold of many vegetable species [17]. For these reasons, many researchers focused their attention on the mechanisms of salt stress adaptation in plants to improve vegetable crop tolerance $[6,18]$. Ionic/hydraulic re-equilibrium, detoxification of reactive oxygen species, and modulation of cell growth or cell division are the main stress response mechanisms that are activated by plants in response to salinity [18]. These mechanisms are triggered by hormonal signaling, as revealed by the modifications of the endogenous levels of phytohormones found in plants, which grow under salt stress $[19,20]$. Thus, some strategies employed to increase salt tolerance of vegetable crops and mitigate the negative effects of salinity focus on the exogenous application of plant growth regulators (gibberellins, auxins, and cytokinins) [16,20], or the inoculation of the rhizosphere with root colonizing bacteria, which produce phytohormones [21,22]. Plant growth-promoting rhizobacteria (PGPR) were shown to minimize salt stress on several vegetable crops $[23,24]$. They enhance plant growth by various mechanisms, such as biocontrol and induction of disease resistance, production of different phytohormones, mineralization and decomposition of organic matter, and improvement of the bioavailability of some mineral nutrients ( $\mathrm{P}$ and $\mathrm{Fe}$ ) [24,25]. Plant growth-promoting bacteria can enhance the growth of many vegetable crops under saline conditions $[25,26]$ but the studies on the application of PGPR on leafy vegetables grown in hydroponics are rather limited and are not used under salt stress conditions. Therefore, this study aimed to evaluate the use of plant growth-promoting bacteria to increase the salt tolerance of leaf lettuce grown in a floating system.

\section{Materials and Methods}

\subsection{Leafy Vegetable Cultivation}

Two experiments were carried out during autumn 2018 and spring 2019 in a greenhouse located at the Department of Agricultural, Food, and Forest Sciences (SAAF-University of Palermo, Italy) $\left(38^{\circ} 6^{\prime} 28^{\prime \prime} \mathrm{N} 13^{\circ} 21^{\prime} 3^{\prime \prime} \mathrm{E}\right.$; altitude $\left.49 \mathrm{~m}\right)$. In both experiments, leaf lettuce plants (Lactuca sativa $\mathrm{L}$. var. Crispa) were cultivated in a hydroponic floating system. Four treatments derived from a factorial combination of two nutrient solution, inoculated or not, with a commercial bacterial biostimulant (TNC Bactorr ${ }^{\mathrm{S} 13}$, The nutrient company, Rochdale, UK) and two $\mathrm{NaCl}$ concentrations $(0$ and $20 \mathrm{mM}$ $\mathrm{NaCl}$ ) [16], were tested for each cultivation season.

The mineral nutrient solutions (MNS) were prepared by adding the following to tap water (electrical conductivity - EC $480 \mu \mathrm{S} \mathrm{cm}{ }^{-1}$; $\mathrm{pH}$ 7.6): $4.5 \mathrm{mmol} \mathrm{L}^{-1}$ of $\mathrm{Ca}^{2+}, 2 \mathrm{mmol} \mathrm{L}{ }^{-1}$ of $\mathrm{H}_{2} \mathrm{PO}_{4}^{-}$, $1.25 \mathrm{mmol} \mathrm{L}^{-1}$ of $\mathrm{NH}_{4}^{+}, 1 \mathrm{mmol} \mathrm{L}-1$ of $\mathrm{Mg}^{2+}, 19 \mathrm{mmol} \mathrm{L}^{-1}$ of $\mathrm{NO}_{3}^{-}, 11 \mathrm{mmol} \mathrm{L}^{-1}$ of K, $1.1 \mathrm{mmol} \mathrm{L}^{-1}$ of $\mathrm{SO}_{4}{ }^{2-}, 40 \mu \mathrm{mol} \mathrm{L}{ }^{-1}$ of $\mathrm{Fe}^{3+}, 5 \mu \mathrm{mol} \mathrm{L}{ }^{-1}$ of $\mathrm{Mn}^{2+}, 4 \mu \mathrm{mol} \mathrm{L}{ }^{-1}$ of $\mathrm{Zn}^{2+}, 30 \mu \mathrm{mol} \mathrm{L}{ }^{-1}$ of $\mathrm{BO}_{3}{ }^{3-}$, $0.75 \mu \mathrm{mol} \mathrm{L}{ }^{-1}$ of $\mathrm{Cu}^{2+}$, and $0.50 \mu \mathrm{mol} \mathrm{L}{ }^{-1}$ of Mo [27]. Four nutrient solutions were prepared, which differed only in bacterial biostimulant and $\mathrm{NaCl}$ concentration. The commercial bacterial biostimulant $\left(1.5 \mathrm{~g} \mathrm{~L}^{-1}\right.$ of TNC Bactorr $\left.{ }^{\mathrm{S} 13}\right)$ contains plant growth-promoting bacteria $\left(1.3 \times 10^{8} \mathrm{CFU} \mathrm{g}^{-1}\right.$ of Bacillus amyloliquefaciens, B. brevis, B. circulans, B. coagulans, B. firmus, B. halodenitrificans, B. laterosporus, 
B. licheniformis, B. megaterium, B. mycoides, B. pasteurii, B. subtilis, Paenibacillus polymyxa), as well as soluble humates, natural plant hormones, amino acids, vitamins, and trace elements derived from Ascophylum nodosum. The MNS had pH 5.8 and an EC of 2.3 and $4.4 \mathrm{mS} \mathrm{cm}^{-1}$ for 0 and $20 \mathrm{mM} \mathrm{NaCl}$, respectively. Four different tanks ( $100 \mathrm{~cm}$ long $\times 50 \mathrm{~cm}$ wide $\times 15 \mathrm{~cm}$ deep, containing $75 \mathrm{~L}$ ) were filled with each nutrient solution. Seedlings of leaf lettuce (cv. 'Lattuga da Taglio a Foglia Liscia', Sementi Dotto-SDD SPA, Udine, Italy), were grown in polystyrene trays (160 holes) and transplanted (23 October 2018 and 18 April 2019) in drilled polystyrene panels (300 plants $\mathrm{m}^{-2}$ ) when they had 3-4 true leaves. The panels were then directly placed to float on the MNS (Figure 1).
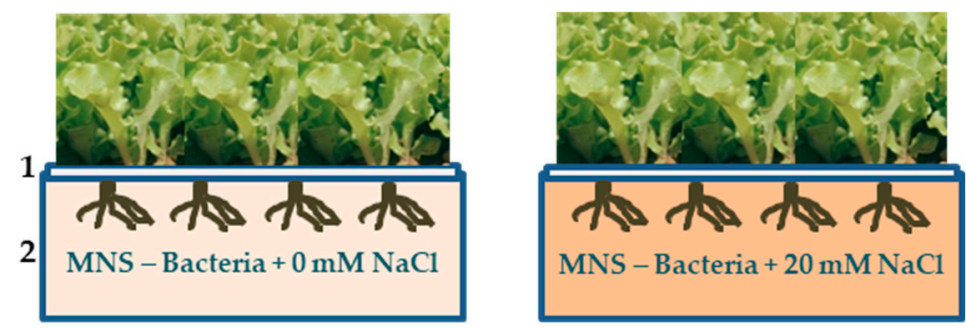

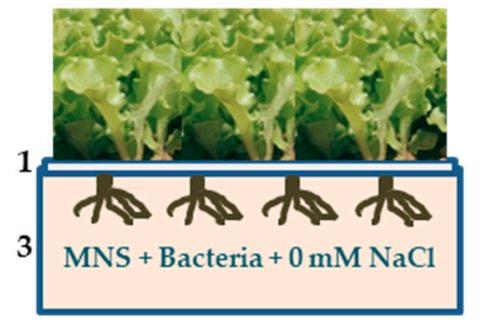

EC $2,3 \mathrm{mS} \mathrm{cm}^{-1}$

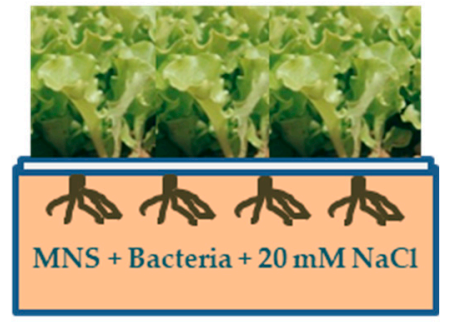

$4,4 \mathrm{mS} \mathrm{cm}^{-1}$

Figure 1. Graphical representation of the hydroponic floating system consisting of drilled polystyrene panels floating on mineral nutrient solutions, with different combinations of bacterial inoculant (Bacteria) and $\mathrm{NaCl}$ levels. ${ }^{(1)}$ Drilled polystyrene panels $\left(300\right.$ plants $\left.\mathrm{m}^{-2}\right)$ floating on a mineral nutrient solution (MNS). Tanks containing $75 \mathrm{~L}$ of MNS added with two concentrations of $\mathrm{NaCl}$ and ${ }^{(2)}$ not inoculated or (3) inoculated with the bacterial inoculant.

Each treatment was composed of four replicated tanks for each combination of bacterial inoculant and $\mathrm{NaCl}$ (150 plants for each tank). The nutrient solutions were aerated during plant growth by insufflating air through PE pipes of $5 \mathrm{~mm}$ diameter, for five minutes, twice every day. The nutrient solutions in each tank were monitored every day to measure temperature, water consumption, and changes of EC and $\mathrm{pH}$. When the volume of MNS consumed by plants overcame $20 \%$, the tanks were refilled with new nutrient solutions, with the same $\mathrm{NaCl}$ concentration. The tanks were completely covered by the polystyrene panels, hence the loss of water due to evaporation was minimal and was not considered [28]. Water use efficiency (WUE) was calculated as WUE ( $\left(\mathrm{DW} \mathrm{L} \mathrm{DW}^{-1} \mathrm{H}_{2} \mathrm{O}\right)=$ plant dry weight $(\mathrm{g}) / \mathrm{H}_{2} \mathrm{O}(\mathrm{L})$. Soon after harvest, the MNS in the tanks was analyzed to calculate the residual amount of nitrogen ( $\mathrm{N}^{-\mathrm{NH}_{4}}{ }^{+}$and $\mathrm{N}-\mathrm{NO}_{3}{ }^{-}$content determined reflectometrically by a Merck RQflex10 reflectometer, according to the company protocols (Merck, Darmstadt, Germany)). From these values and the volume of nutrient solution consumed by the plants, the total $\mathrm{N}$ uptake during the crop cycle was estimated and the Nitrogen use efficiency (NUE) [29] was calculated as NUE ( $\mathrm{g} \mathrm{DW} \mathrm{g}^{-1} \mathrm{~N}$ ) = plant total dry weight $(\mathrm{g}) /$ plant $\mathrm{N}$ uptake $(\mathrm{g})$.

Stomatal conductance was estimated 15 days after transplant in each growing season, using a diffusion porometer (AP4, Delta-T Devices Ltd., Cambridge, UK) on two recently expanded, unshaded leaves of 20 plant, for each replicate.

All plants were harvested 22 and $20 \mathrm{~d}$ after transplant in autumn and spring, respectively. Marketable yield was calculated after eliminating decayed or yellowed older leaves, then, 20 plants for 
each replicate were randomly selected for destructive testing. Plant height, leaf number, and leaf area were determined. Leaf area was measured for each plant through digital image analysis. Leaves were detached from plants, weighed, and immediately scanned with a resolution of $350 \mathrm{dpi}$ (Epson Perfection 4180 Photo, Seiko Epson Corp. Suwa, Japan); the images were analyzed with the ImageJ 1.52a software (National Institutes Health, Bethesda, MD, USA). Scanned leaves were dried at $85^{\circ} \mathrm{C}$ to a constant weight and re-weighed, in order to calculate the specific leaf area $\left(\mathrm{SLA} \mathrm{cm}^{2} \mathrm{~g}^{-1}\right)$ as leaf area/leaf dry weight. Subsequently, another sample of 20 plants randomly selected for each replicate were weighed after separation in shoot and roots fractions, and then dried to constant weight at $85^{\circ} \mathrm{C}$, for fresh and dry biomass determination.

A third sample (20 plants for each replicate) was used for measuring leaf color and determining soluble solids, ascorbic acid, and nitrate contents. Leaf color was measured with a colorimeter (CR-400, Minolta corporation, Ltd., Osaka, Japan) at two areas of photosynthetic tissue, on the upper part of twenty leaves that were randomly selected for each treatment. It recorded $L^{*}$ (lightness), $a^{*}$ (positive values for reddish colors and negative values for greenish colors), and $b^{*}$ (positive values for yellowish colors and negative values for bluish colors) parameters that were used to calculate hue angle $\left(\mathrm{h}^{\circ}\right)$ and chroma $\left(C^{*}\right)$ as $h^{\circ}=180^{\circ}+\arctan \left(b^{*} / a^{*}\right)[30]$ and $C^{*}=\left(a^{* 2}+b^{* 2}\right)^{1 / 2}$. A sub-sample of leaves $(20 \mathrm{~g})$ from each replicate was then homogenized with $\mathrm{H}_{2} \mathrm{O}(1: 2 \mathrm{w} / \mathrm{v})$ and the homogenates were centrifuged at $3500 \mathrm{rpm}$ for $10 \mathrm{~min}$. Total soluble solids (TSS, expressed as ${ }^{\circ}$ Brix) determination was performed with a digital refractometer (MTD-045nD, Three-In-One Enterprises Co. Ltd., New Taipei City, Taiwan). Ascorbic acid and nitrate contents (expressed as mg $100 \mathrm{~g}^{-1}$ and $\mathrm{mg} \mathrm{kg}^{-1}$ of fresh weight, respectively) were evaluated with a Merck RQflex10 reflectometer, according to the company protocols (Merck, Darmstadt, Germany) [31-33].

\subsection{Statistics and Principal Component Analysis}

The experimental design consisted of four replicates for each combination of bacterial inoculant and $\mathrm{NaCl}$, randomly assigned to four blocks. To determine the effect of cultivation season, bacterial inoculant, and $\mathrm{NaCl}$ concentration on leaf lettuce plants, a three-way ANOVA was carried out. The significance of the differences between treatments and of the interaction between factors was determined by the least significant differences (LSD) test at $p \leq 5 \%$.

The main parameters that were most effective in discriminating among salt stress levels and bacterial inoculant in both cultivation seasons were studied by performing a principal component analysis (PCA) on morpho-physiological and phytochemical parameters of leaf lettuce plants. The input matrix for the analysis included plant height, whole plant fresh weight (FW), shoot (S) FW, roots (R) FW, R/S FW, whole plant dry weight (DW), shoot DW, roots DW, R/S DW, dry matter percentage, yield, minimal processing yield, WUE, NUE, leaf number, plant area, leaf area, SLA, stomatal

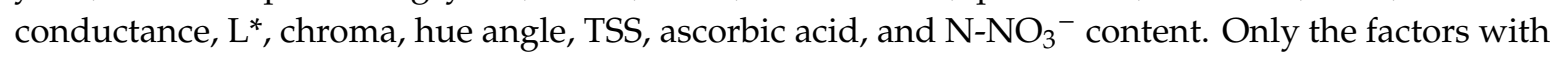
eigenvalues higher than 1.0 were retained to assess the optimum number of principal components (PCs). Additionally, the plot of the PCs allowed investigating the correlations between the variables of the input data set. In this context, the studied variables were projected into the subspace defined by the first and second PCs, and the correlated variables were calculated. The principal component analysis was performed with SPSS version 13.0 (SPSS Inc., Chicago, IL, USA).

\section{Results}

Leaf lettuce cultivation was carried out in a floating system in both cultivation seasons. The hydroponic system consisted of polystyrene panels floating on the mineral nutrient solution (MNS).

The average temperature outside the greenhouse, during the experiments, ranged between $31.4 \pm 0.6{ }^{\circ} \mathrm{C}$ (day) and $10.1 \pm 0.3{ }^{\circ} \mathrm{C}$ (night) in autumn and between $27.7 \pm 0.5{ }^{\circ} \mathrm{C}$ (day) and $11.4 \pm 0.3^{\circ} \mathrm{C}$ (night) in spring. The average net solar radiation at noon was 445 and $695 \mathrm{~W} \cdot \mathrm{m}^{-2}$ in autumn and spring, respectively. The day length during the autumn cultivation period ranged between 8 and $9 \mathrm{~h}$ and lasted 11-12 h in spring. During the first experiment (autumn), the mean 
air and MNS temperatures inside the greenhouse were $21.9 \pm 0.6{ }^{\circ} \mathrm{C}$ and $21.4 \pm 0.3{ }^{\circ} \mathrm{C}$, respectively (Figure 2); the air temperature ranged between 36.6 (day) and $11.9^{\circ} \mathrm{C}$ (night); relative humidity was on average $86.0 \%$ and ranged between $59.9 \%$ and $100 \%$; the highest light intensity inside the greenhouse was 38,728 lux on average, ranging from 55,221 to 1,286 lux as a function of the cloudiness. During the second experiment (spring), the mean air and MNS temperatures inside the greenhouse were $22.1 \pm 0.5^{\circ} \mathrm{C}$ and $20.6 \pm 0.4{ }^{\circ} \mathrm{C}$, respectively; the air temperature ranged between 36.9 (day) and $11.1^{\circ} \mathrm{C}$ (night); relative humidity was on average $75.2 \%$ and ranged between $49.2 \%$ and $99.0 \%$; the highest light intensity inside the greenhouse was 59,271 lux on average, ranging from 83,586 to 12,462 lux, as a function of the cloudiness.

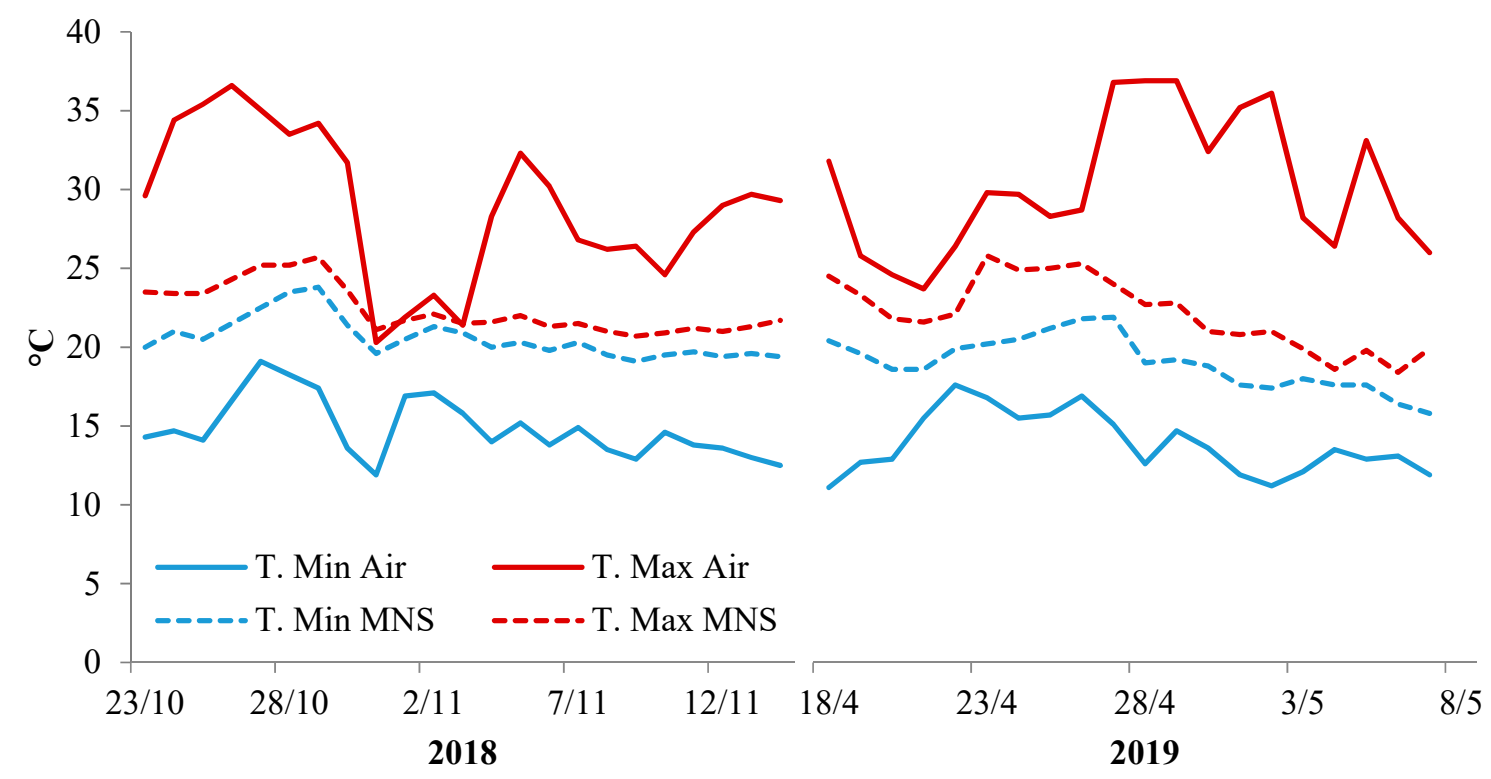

Figure 2. Daily average maximum and minimum temperatures of the air and mineral nutrient solutions (MNS) inside the greenhouse during autumn 2018 and spring 2019 cultivations.

The EC and $\mathrm{pH}$ values of the nutrient solutions in the tanks varied during plant growth and between growing seasons. The $\mathrm{pH}$ increased up to 6.89 and 6.50 for autumn and spring cultivations, respectively, regardless of the bacterial inoculum or salt content. The EC of MNS had significant differences due to water absorption and refills of the tanks with MNS with different $\mathrm{NaCl}$ concentrations. The MNS decreased their EC, during autumn cultivation, in control tanks $\left(1.82 \mathrm{mS} \mathrm{cm}^{-1}\right.$ on average for $0 \mathrm{mM} \mathrm{NaCl})$, whereas, it increased in the MNS with $20 \mathrm{mM} \mathrm{NaCl}\left(6.26 \mathrm{mS} \mathrm{cm}^{-1}\right)$. Slightly higher EC values were found for the MNS of the second experiment, which raised up to 3.07 and $6.56 \mathrm{mS} \mathrm{cm}^{-1}$ for 0 and $20 \mathrm{mM} \mathrm{NaCl}$, respectively.

\subsection{Morphophysiological Parameters and Yield of Leaf Lettuce}

The characteristics of lettuce plants evaluated during the experiments were influenced by the season of cultivation. Moreover, the climatic condition of the cultivation periods significantly interacted with one or both experimental factors (bacterial biostimulant and $\mathrm{NaCl}$ ). The height of the plants at harvest was higher in autumn than in spring. The highest plant height in autumn was measured in all inoculated plants and in the uninoculated plants grown with $0 \mathrm{mM} \mathrm{NaCl}$ in the nutrient solution ( $25.1 \mathrm{~cm}$ on average), whereas control plants under salt stress reduced their height by $14.3 \%$ (Table 1, Figure 3). At the end of the second experiment (spring), plant height was reduced by salt stress, in both control and inoculated plants ( $-15.6 \%$ and $-15.3 \%$, respectively), but inoculated and salt-stressed lettuce plants were $19.4 \mathrm{~cm}$ high and did not differ significantly from uninoculated and unstressed plants. 
Table 1. Morphological parameters of leaf lettuce plants grown during autumn and spring in nutrient solutions containing different levels of $\mathrm{NaCl}$ and bacterial biostimulant.

\begin{tabular}{|c|c|c|c|c|c|c|c|c|c|c|c|}
\hline \multirow{2}{*}{\multicolumn{2}{|c|}{ Source of Variance }} & \multirow{2}{*}{$\begin{array}{c}\text { Plant Height } \\
(\mathrm{cm})\end{array}$} & \multicolumn{4}{|c|}{ Fresh Weight (g plant ${ }^{-1}$ ) } & \multicolumn{4}{|c|}{ Dry Weight (g plant ${ }^{-1}$ ) } & \multirow{2}{*}{$\begin{array}{c}\text { Dry Matter } \\
(\%)\end{array}$} \\
\hline & & & Total & $\begin{array}{l}\text { Shoot } \\
\text { (S) }\end{array}$ & $\begin{array}{c}\text { Root } \\
\text { (R) }\end{array}$ & $\mathrm{R} / \mathrm{S}$ & Total & $\begin{array}{c}\text { Shoot } \\
\text { (S) }\end{array}$ & $\begin{array}{l}\text { Root } \\
\text { (R) }\end{array}$ & $\mathrm{R} / \mathrm{S}$ & \\
\hline \multicolumn{12}{|c|}{ Season } \\
\hline Autu & & z 24.2 & 19.0 & 14.1 & 4.9 & 0.35 & 1.20 & 0.93 & 0.27 & 0.29 & 6.6 \\
\hline Spri & & 19.2 & 14.7 & 12.6 & 2.1 & 0.17 & 0.99 & 0.86 & 0.13 & 0.15 & 6.8 \\
\hline \multicolumn{12}{|c|}{ PGPR } \\
\hline$-\mathrm{E}$ & & 20.3 & 14.7 & 11.7 & 3.0 & 0.25 & 0.94 & 0.77 & 0.16 & 0.21 & 6.7 \\
\hline$+\mathrm{E}$ & & 23.1 & 19.0 & 15.0 & 4.0 & 0.27 & 1.26 & 1.02 & 0.24 & 0.24 & 6.8 \\
\hline \multicolumn{12}{|c|}{$\mathrm{NaCl}(\mathrm{mM})$} \\
\hline 0 & & 22.9 & 18.3 & 14.8 & 3.5 & 0.23 & 1.14 & 0.96 & 0.18 & 0.19 & 6.4 \\
\hline 20 & & 20.5 & 15.5 & 11.9 & 3.6 & 0.29 & 1.05 & 0.83 & 0.23 & 0.26 & 7.0 \\
\hline \multicolumn{12}{|c|}{ Season $\times$ PGPR } \\
\hline \multirow[t]{2}{*}{ Autumn } & $-B$ & 23.3 & $17.5 b$ & 13.0 & 4.5 & 0.35 & 1.06 & $0.84 b$ & 0.22 & 0.26 & 6.5 \\
\hline & $+\mathrm{B}$ & 25.1 & $20.6 a$ & 15.2 & 5.4 & 0.36 & 1.35 & $1.02 \mathrm{a}$ & 0.33 & 0.32 & 6.7 \\
\hline \multirow[t]{2}{*}{ Spring } & $-B$ & 17.2 & $12.0 \mathrm{c}$ & 10.4 & 1.6 & 0.15 & 0.81 & $0.70 \mathrm{c}$ & 0.10 & 0.15 & 6.9 \\
\hline & $+\mathrm{B}$ & 21.1 & $17.5 b$ & 14.8 & 2.7 & 0.18 & 1.17 & $1.01 \mathrm{a}$ & 0.16 & 0.16 & 6.8 \\
\hline \multicolumn{12}{|c|}{ Season $\times \mathrm{NaCl}$} \\
\hline \multirow[t]{2}{*}{ Autumn } & 0 & 25.1 & $19.2 \mathrm{a}$ & 14.9 & $4.3 b$ & $0.29 b$ & $1.17 \mathrm{ab}$ & $0.96 a$ & $0.21 b$ & $0.22 b$ & 6.4 \\
\hline & 20 & 23.4 & $18.8 \mathrm{ab}$ & 13.3 & $5.5 \mathrm{a}$ & $0.42 \mathrm{a}$ & $1.24 \mathrm{a}$ & $0.90 \mathrm{a}$ & $0.34 \mathrm{a}$ & $0.37 \mathrm{a}$ & 6.8 \\
\hline \multirow[t]{2}{*}{ Spring } & 0 & 20.8 & $17.3 b$ & 14.7 & $2.6 \mathrm{c}$ & $0.18 \mathrm{c}$ & $1.11 \mathrm{~b}$ & $0.96 a$ & $0.15 b c$ & $0.16 b$ & 6.5 \\
\hline & 20 & 17.6 & $12.2 \mathrm{c}$ & 10.5 & $1.7 \mathrm{~d}$ & $0.16 c$ & $0.87 \mathrm{c}$ & $0.75 b$ & $0.11 \mathrm{c}$ & $0.15 b$ & 7.2 \\
\hline \multicolumn{12}{|c|}{ PGPR $\times \mathrm{NaCl}$} \\
\hline \multirow[t]{2}{*}{$-\mathrm{B}$} & 0 & 21.9 & 15.7 & 12.8 & 2.9 & 0.22 & $0.92 \mathrm{c}$ & $0.78 \mathrm{c}$ & 0.14 & 0.18 & $6.1 b$ \\
\hline & 20 & 18.7 & 13.7 & 10.6 & 3.1 & 0.27 & $0.95 c$ & $0.77 \mathrm{c}$ & 0.18 & 0.23 & $7.3 \mathrm{a}$ \\
\hline \multirow[t]{2}{*}{$+\mathrm{B}$} & 0 & 23.9 & 20.9 & 16.9 & 4.0 & 0.24 & $1.36 \mathrm{a}$ & $1.14 \mathrm{a}$ & 0.22 & 0.19 & $6.8 \mathrm{a}$ \\
\hline & 20 & 22.3 & 17.2 & 13.1 & 4.1 & 0.30 & $1.15 b$ & $0.89 b$ & 0.27 & 0.29 & $6.8 \mathrm{a}$ \\
\hline \multicolumn{12}{|c|}{ Significance ${ }^{x}$} \\
\hline Season & & $* * *$ & $* * *$ & $* * *$ & $* * *$ & $* * *$ & $* * *$ & $*$ & $* * *$ & $* * *$ & ns \\
\hline PGPR & & $* * *$ & $* * *$ & $* * *$ & $* * *$ & ns & $* * *$ & $* * *$ & $* * *$ & ns & ns \\
\hline $\mathrm{NaCl}$ & & $* * *$ & $* * *$ & $* * *$ & ns & $* * *$ & * & $* * *$ & * & $* *$ & $* * *$ \\
\hline Season $x$ & & $* *$ & $* *$ & $* *$ & ns & ns & ns & * & ns & ns & ns \\
\hline Season $>$ & & $*$ & $* * *$ & $* * *$ & $* * *$ & $* * *$ & $* * *$ & $*$ & $* * *$ & $* * *$ & ns \\
\hline PGPR $\times$ & & * & ns & * & ns & ns & $* *$ & $* * *$ & ns & ns & $* * *$ \\
\hline Season $\times$ PG & $\mathrm{NaCl}$ & $* *$ & ns & * & ns & ns & ns & ns & ns & ns & ns \\
\hline
\end{tabular}

${ }^{\mathrm{z}}$ Each value is the mean of 4 replicated samples of 20 plants each. For each factor, values in a column followed by the same letter are not significantly different, according to the LSD test. ${ }^{x}$ Significance: $\mathrm{ns}=$ not significant; ${ }^{*}$ significant at $p<0.05 ;{ }^{* *}$ significant at $p<0.01 ;{ }^{* * *}$ significant at $p<0.001$.

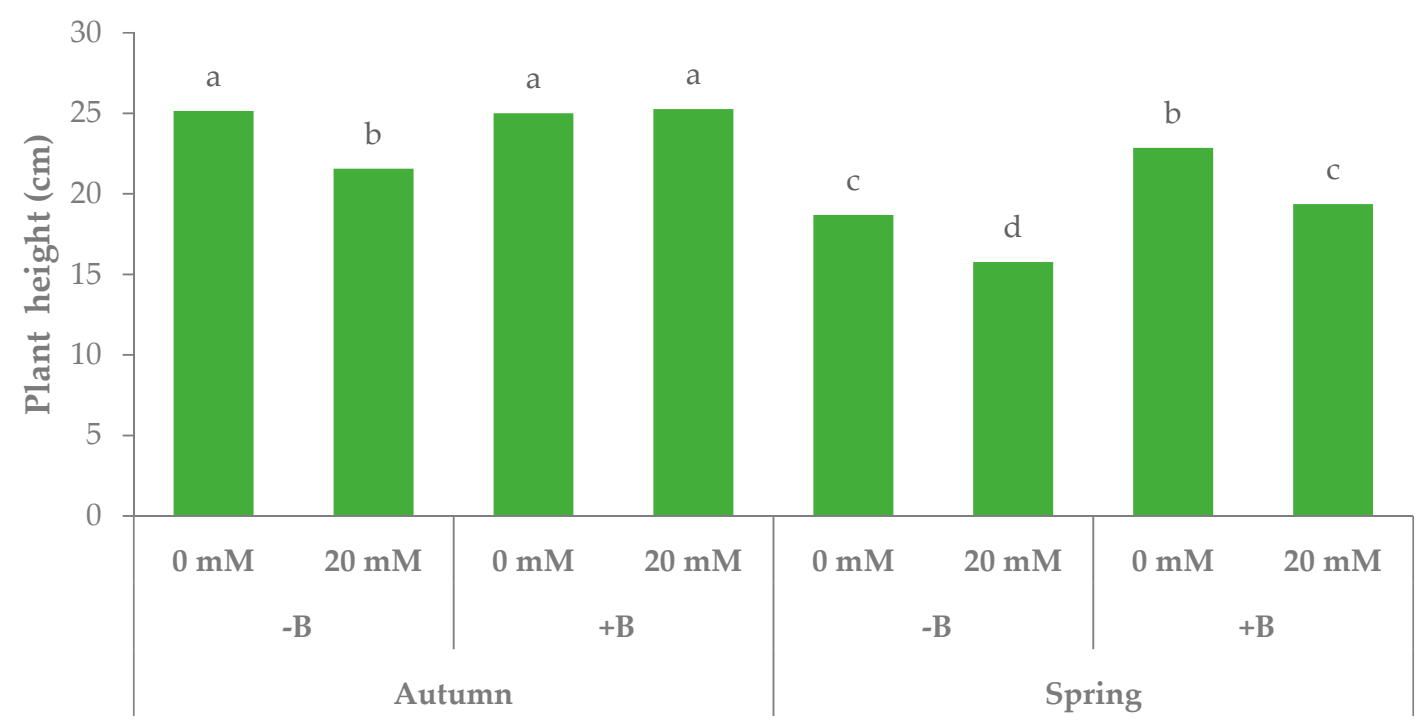

Figure 3. Height of leaf lettuce plants grown during autumn and spring in nutrient solutions containing different levels of $\mathrm{NaCl}(0 \mathrm{mM}$ and $20 \mathrm{mM})$ and with $(+\mathrm{B})$ or without $(-\mathrm{B})$ bacterial biostimulant (bars with different letters are significantly different at $p<0.05$, according to the LSD test). 
The total fresh biomass accumulated by the plants was influenced by all experimental factors but the effect of PGPR and salt stress showed some differences as a function of cultivation season (Table 1). In the first experiment, the total fresh weight (FW) of lettuce plants was $17.5 \mathrm{~g} \mathrm{FW} \mathrm{plant}^{-1}$ on average, in non-inoculated nutrient solutions, and increased by $17.8 \%$ in the plants grown in inoculated MNS. In the second cultivation season, the fresh biomass was lower than the first in the uninoculated plants and showed a greater effect of the bacterial biostimulant that increased the plant fresh weight by $46.0 \%$ (Table 1, Figure 4a). With regards to salt stress, a small and non-significant reduction was determined during the first experiment, whereas its effect was greater in the second experiment which recorded the lowest fresh weight in salt-stressed plants (12.2 g FW plant ${ }^{-1}$ on average, $-29.9 \%$ ) (Table 1, Figure 4b).

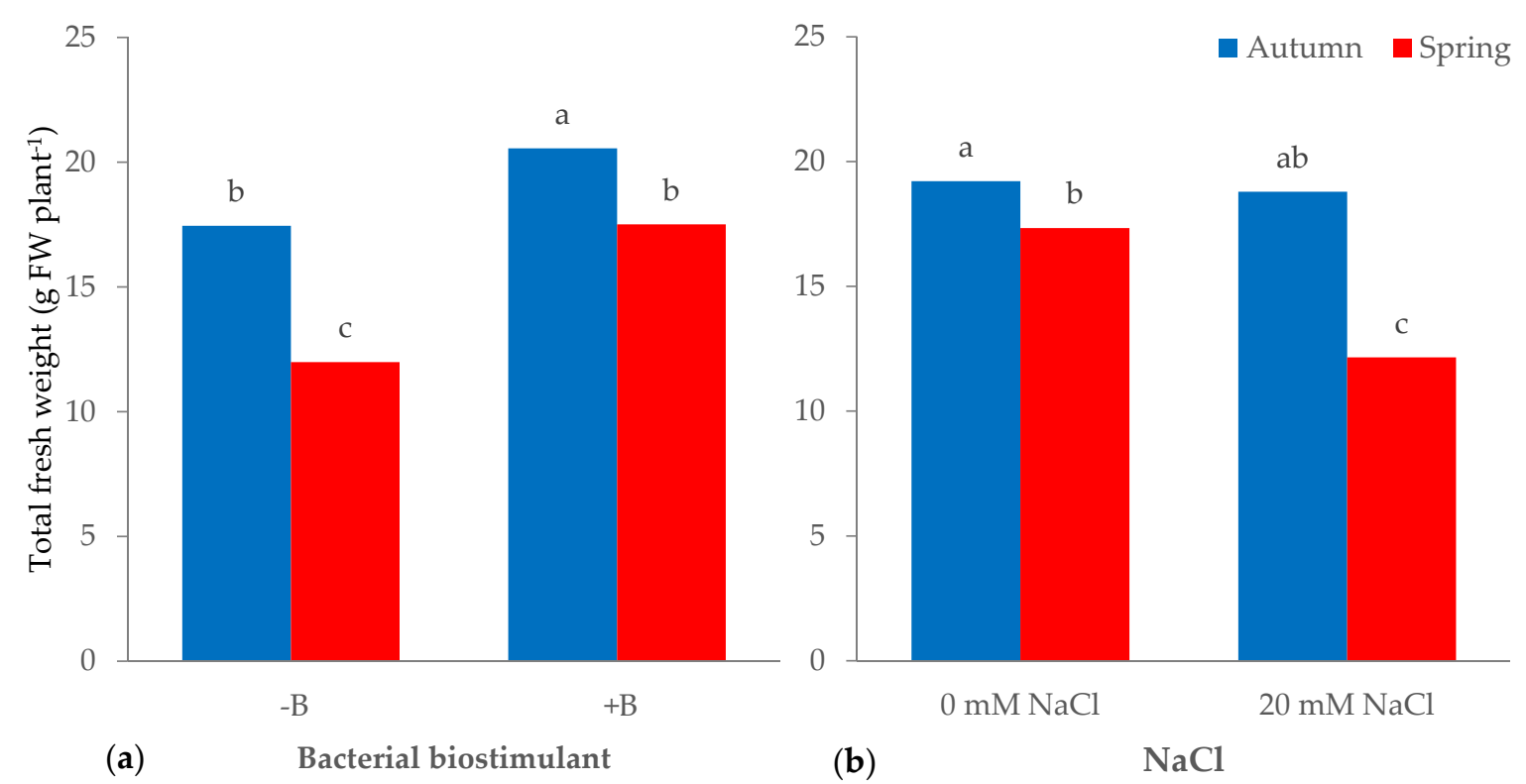

Figure 4. Total fresh weight of leaf lettuce plants grown during autumn and spring in nutrient solutions (a) with $(+\mathrm{B})$ or without $(-\mathrm{B})$ bacterial biostimulant or $(\mathbf{b})$ containing different levels of $\mathrm{NaCl}$ (for each interaction, bars with different letters are significantly different at $p<0.05$, according to the LSD test).

The main part of the biomass was represented by the shoot (leaves and stem). The fresh biomass of the shoots was higher in the first season. In both seasons, inoculated salt-stressed plants accumulated more fresh biomass in the shoots (Table 1, Figure 5). Salt stress determined modest and non-significant reductions in the first season $(-11.3 \%$ and $-10.7 \%$ for uninoculated and inoculated plants, respectively), when salt-stressed inoculated plants had a shoot fresh weight similar to the unstressed uninoculated plants. During spring cultivation, the shoot of the uninoculated plants weighed $11.8 \mathrm{~g} \mathrm{FW} \mathrm{plant}^{-1}$, under no salt stress and dropped by $23.4 \%$ in the salt stress conditions. The shoot fresh weight of the inoculated unstressed plants showed no significant difference against the same treatment of the first growing season and, even if salt stress determined a reduction of 32.7\% in the second season, the shoot weight of salt-stressed inoculated plants was comparable to that of uninoculated unstressed plants (Table 1, Figure 5). The fresh biomass of the roots was greater during autumn than spring and was significantly stimulated by the bacterial inoculum ( $+33.4 \%$ on average). Salt stress determined a contrasting effect on root fresh weight as a function of cultivation season. Salinity increased the fresh biomass of the roots during the first experiment $(+27.8 \%)$, whereas it decreased in the second experiment $(-35.1 \%)$ (Table 1$)$.

The modification of fresh biomass partitioning due to the experimental factors was shown by the root/shoot ratio of the fresh weight (Table 1). During spring, the allocation of biomass in the roots was lower than in autumn. The bacterial biostimulant did not affect the R/S ratio, whereas salinity had a different effect in each growing season, as it increased the R/S ratio in autumn (from 0.29 to 0.42 on average for 0 and $20 \mathrm{~mm} \mathrm{NaCl}$, respectively) but had no significant effect in spring. 


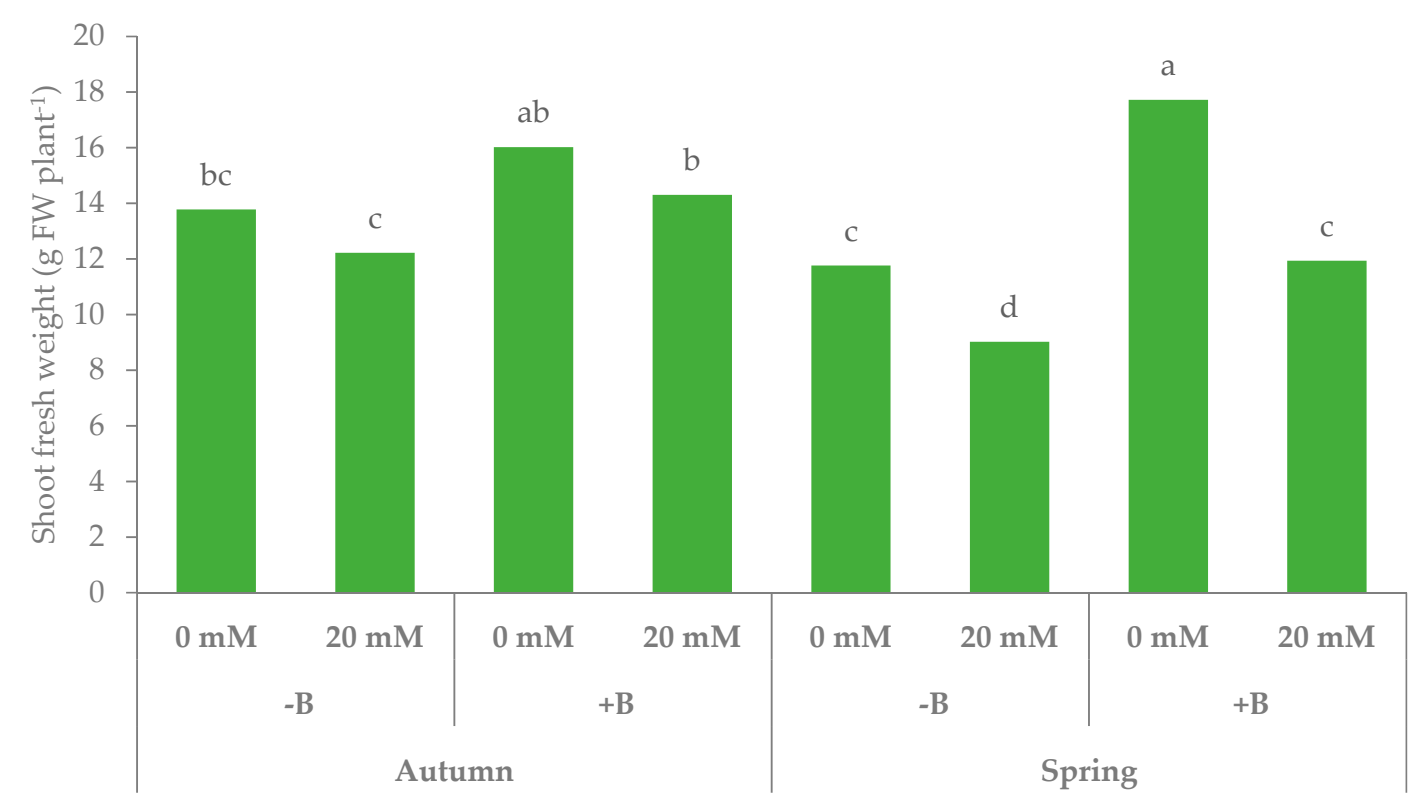

Figure 5. Shoot fresh weight of leaf lettuce plants grown during autumn and spring in nutrient solutions containing different levels of $\mathrm{NaCl}(0 \mathrm{mM}$ and $20 \mathrm{mM})$ and with $(+\mathrm{B})$ or without $(-\mathrm{B})$ bacterial biostimulant (bars with different letters are significantly different at $p<0.05$, according to the LSD test).

The experimental factors also affected the dry weight (DW) of lettuce plants (Table 1). During the first experiment, the plants accumulated $1.17 \mathrm{~g}^{\mathrm{DW}}$ plant $^{-1}$ with $0 \mathrm{mM} \mathrm{NaCl}$ in the $\mathrm{MNS}$ and showed a slight but not significant increase under salt stress, whereas, in the second cultivation season, salinity determined a significant decrease of total dry weight $(22.1 \%)$ as compared to the unstressed plants. The plants not inoculated with the bacterial biostimulant had a lower dry biomass accumulation (0.94 $\mathrm{g} \mathrm{DW} \mathrm{plant}^{-1}$ on average), irrespective of salt stress. The bacterial biostimulant promoted the accumulation of dry biomass up to $1.36 \mathrm{~g} \mathrm{DW} \mathrm{plant}^{-1}$ without salt stress, and, even if salt stress reduced the total dry weight of lettuce plants by $15.3 \%$, the dry biomass accumulated in those plants was significantly higher than that of uninoculated plants (Table 1). The dry biomass accumulated in the shoot of the uninoculated plants was 0.84 and $0.70 \mathrm{~g} \mathrm{DW} \mathrm{plant}^{-1}$ in autumn and spring, respectively. The bacterial biostimulant increased the dry weight of the shoot up to $1.02 \mathrm{~g} \mathrm{DW} \mathrm{plant}^{-1}$ on average in both seasons. The dry weight of the shoot was $0.96 \mathrm{~g} \mathrm{DW} \mathrm{plant}^{-1}$ on average in both seasons, when plants were grown without $\mathrm{NaCl}$ in the MNS. Salt stress did not significantly affect this parameter in the first season, whereas it decreased down to $0.75 \mathrm{~g} \mathrm{DW} \mathrm{plant}^{-1}$ on average during spring cultivation. Moreover, similar to what was observed for the total dry weight, salt stress negatively affected only the shoot dry weight of the inoculated plants, which in any case, had a higher biomass accumulation than the uninoculated plants. PGPR had a positive effect on dry biomass accumulation in the roots. The dry weight of the roots increased under salt stress during autumn but was not influenced by salinity.

The variations recorded during the experiments on dry matter percentage were mainly found in the plant not inoculated with PGPR, which increased up to $7.3 \%$ under salt stress $(+19.9 \%$ than unstressed plants), whereas the plants inoculated with the bacterial biostimulant did not change their dry matter percentage as a function of salt stress (Table 1 ).

The plants grown without bacterial biostimulant in the MNS yielded $3.0 \mathrm{~kg} \mathrm{~m}^{-2}$ on average in autumn and significantly less in spring, while those grown in MNS inoculated with PGPR yielded significantly more in both season $\left(3.4 \mathrm{~kg} \mathrm{~m}^{-2}\right.$ on average) (Table 2, Figure 6a). The plants of lettuce not subjected to salt stress yielded $3.5 \mathrm{~kg} \mathrm{~m}^{-2}$ on average in both cultivation seasons (Table 2, Figure 6b); the use of MNS with $\mathrm{NaCl}$ determined a reduction of the crop yield that was lower in autumn $(-18.3 \%)$ than in spring $(-28.6 \%)$. The supply of bacterial biostimulant in brackish MNS allowed the plants to reach a crop yield similar to those grown without PGPR and $0 \mathrm{mM} \mathrm{NaCl}$ in both seasons. The minimal 
processing yield was affected only by the salt stress, which slightly increased the percentage of leaves suitable to be processed as fresh-cut vegetables. Despite this increase, the yield of minimally processed leaves were affected by the experimental factor in the same way as that of the crop yield (Table 2).

Table 2. Yield parameters of leaf lettuce plants grown during autumn and spring in nutrient solutions containing different levels of $\mathrm{NaCl}$ and bacterial biostimulant.

\begin{tabular}{|c|c|c|c|c|c|c|}
\hline \multicolumn{2}{|c|}{ Source of Variance } & $\begin{array}{l}\text { Crop Yield } \\
\left(\mathrm{kg} \mathrm{m}^{2}\right)\end{array}$ & $\begin{array}{c}\text { Minimal } \\
\text { Processing Yield } \\
(\%)\end{array}$ & $\begin{array}{c}\text { Leaf Yield } \\
\left(\mathrm{kg} \mathrm{m}^{2}\right)\end{array}$ & $\begin{array}{l}\text { WUE (g DW } \\
\mathrm{L}^{-1} \mathrm{H}_{2} \mathrm{O} \text { ) }\end{array}$ & $\begin{array}{l}\text { NUE (g DW } \\
\left.\mathrm{g}^{-1} \mathrm{~N}\right)\end{array}$ \\
\hline \multicolumn{7}{|c|}{ Season } \\
\hline \multicolumn{2}{|c|}{ Autumn } & $\mathrm{z} 3.2$ & 89.5 & 2.9 & 3.2 & 23.2 \\
\hline \multirow{2}{*}{\multicolumn{7}{|c|}{$\begin{array}{l}\text { Spring } \\
\text { PGPR }\end{array}$}} \\
\hline & & & & & & \\
\hline \multicolumn{2}{|c|}{$-B$} & 2.7 & 90.7 & 2.4 & 2.6 & 15.4 \\
\hline \multicolumn{2}{|c|}{$+\mathrm{B}$} & 3.4 & 89.4 & 3.0 & 3.2 & 18.8 \\
\hline \multicolumn{7}{|c|}{$\mathrm{NaCl}(\mathrm{mM})$} \\
\hline \multicolumn{2}{|c|}{0} & 3.5 & $89.0 \mathrm{~b}$ & 3.0 & 2.9 & 16.6 \\
\hline \multicolumn{2}{|c|}{20} & 2.7 & $91.0 \mathrm{a}$ & 2.4 & 2.8 & 17.7 \\
\hline \multicolumn{7}{|c|}{ Season $\times$ PGPR } \\
\hline \multirow[t]{2}{*}{ Autumn } & $-B$ & $3.0 \mathrm{~b}$ & 90.6 & $2.7 \mathrm{~b}$ & $3.0 \mathrm{~b}$ & 21.6 \\
\hline & $+\mathrm{B}$ & $3.5 \mathrm{a}$ & 88.3 & $3.0 \mathrm{a}$ & $3.4 \mathrm{a}$ & 24.7 \\
\hline \multirow{2}{*}{ Spring } & $-B$ & $2.5 \mathrm{c}$ & 90.9 & $2.2 \mathrm{c}$ & $2.2 \mathrm{c}$ & 9.3 \\
\hline & $+\mathrm{B}$ & $3.3 a$ & 90.4 & $3.0 \mathrm{a}$ & $3.0 \mathrm{~b}$ & 12.9 \\
\hline \multicolumn{7}{|c|}{ Season $\times \mathrm{NaCl}$} \\
\hline \multirow[t]{2}{*}{ Autumn } & 0 & $3.6 \mathrm{a}$ & 87.7 & $3.0 \mathrm{a}$ & $3.1 \mathrm{a}$ & $21.4 b$ \\
\hline & 20 & $2.9 \mathrm{~b}$ & 91.2 & $2.7 \mathrm{~b}$ & $3.3 \mathrm{a}$ & $24.9 a$ \\
\hline \multirow[t]{2}{*}{ Spring } & 0 & $3.4 \mathrm{a}$ & 90.4 & $3.0 \mathrm{a}$ & $2.7 \mathrm{~b}$ & $11.8 \mathrm{c}$ \\
\hline & 20 & $2.4 \mathrm{c}$ & 90.9 & $2.2 \mathrm{c}$ & $2.4 \mathrm{c}$ & $10.4 \mathrm{c}$ \\
\hline \multicolumn{7}{|c|}{ PGPR $\times \mathrm{NaCl}$} \\
\hline \multirow[t]{2}{*}{$-B$} & 0 & 3.1 & 89.6 & 2.7 & $2.3 c$ & $13.6 c$ \\
\hline & 20 & 2.4 & 91.9 & 2.2 & $2.8 \mathrm{~b}$ & $17.3 b$ \\
\hline \multirow[t]{2}{*}{$+\mathrm{B}$} & 0 & 3.9 & 88.5 & 3.4 & $3.5 \mathrm{a}$ & $19.6 a$ \\
\hline & 20 & 3.0 & 90.2 & 2.7 & $2.8 \mathrm{~b}$ & $18.0 \mathrm{ab}$ \\
\hline \multicolumn{7}{|c|}{ Significance $\mathrm{x}^{20}$} \\
\hline & & $* * *$ & ns & $* *$ & $* * *$ & $* * *$ \\
\hline & & $* * *$ & ns & $* * *$ & $* * *$ & $* * *$ \\
\hline & & $* * *$ & $*$ & $* * *$ & ns & $\mathrm{ns}$ \\
\hline Season & & * & ns & $* *$ & $* * *$ & ns \\
\hline Season & & * & ns & $* * *$ & $* * *$ & $* * *$ \\
\hline PGPR & & ns & ns & ns & $* * *$ & $* * *$ \\
\hline Season $\times P$ & $\mathrm{NaCl}$ & ns & $\mathrm{ns}$ & ns & ns & $\mathrm{ns}$ \\
\hline
\end{tabular}

${ }^{\mathrm{z}}$ Each value is the mean of 4 replicated samples of 150 plants each. For each factor, values in a column followed by the same letter are not significantly different, according to the LSD test. ${ }^{x}$ Significance: ns $=$ not significant; ${ }^{*}$ significant at $p<0.05 ;{ }^{* *}$ significant at $p<0.01 ;{ }^{* * *}$ significant at $p<0.001$.

During plant growth in every cultivation season, the MNS consumed by the plants was regularly recorded and reintegrated for each tank. From these consumptions, we calculated the water use efficiency (WUE) and nitrogen use efficiency (NUE) (Table 2). WUE was higher during autumn than spring when the salt stress determined a significant reduction. The lowest WUE of the inoculated plants grown in spring or under salt stress was higher than that in the uninoculated plants grown in autumn or under salt stress. NUE was higher in the first experiment when salt stress was effective in increasing it. Salt stress also increased NUE in the plants grown without bacterial biostimulant in the MNS, whereas the plants inoculated with PGPR showed the highest NUE that was not significantly reduced by brackish MNS. 

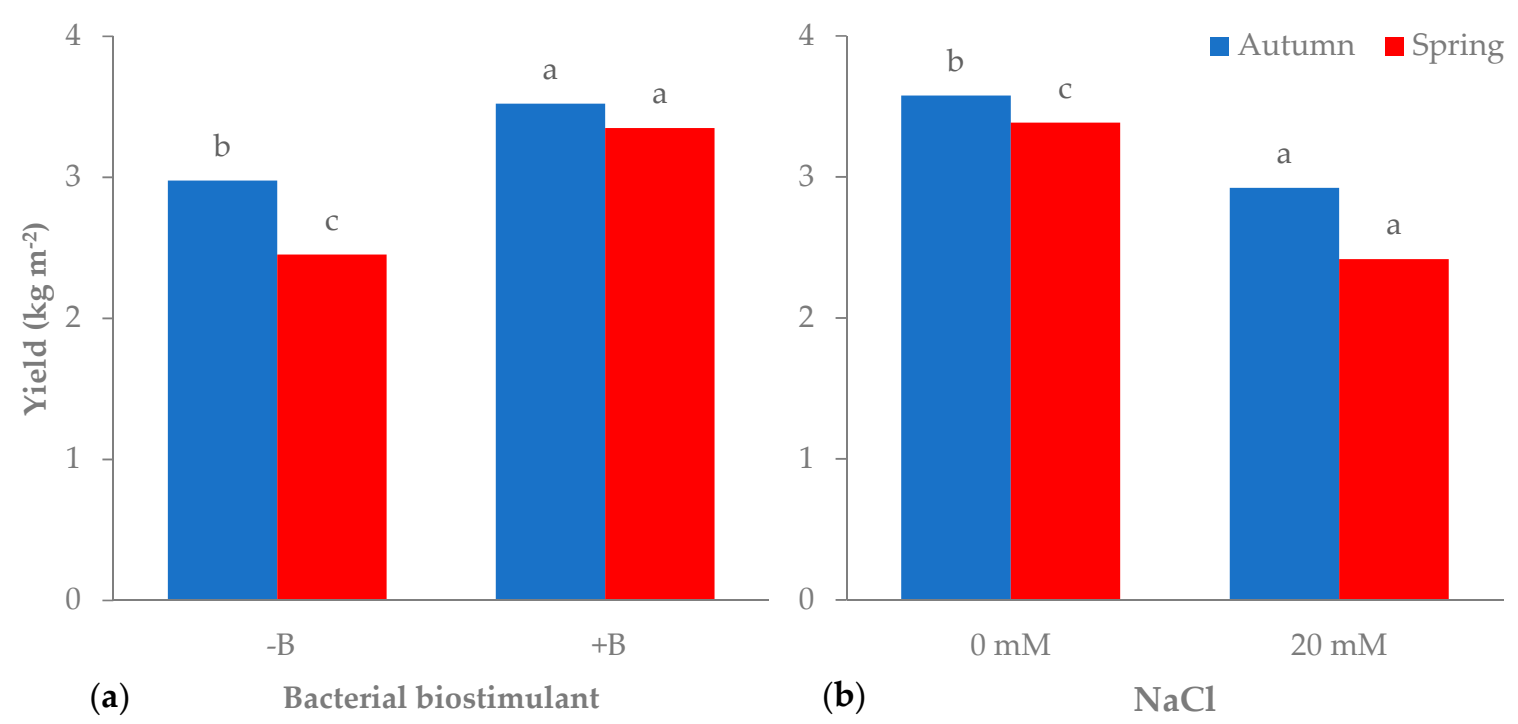

Figure 6. Yield of leaf lettuce plants grown during autumn and spring in nutrient solutions (a) with (+B) or without $(-\mathrm{B})$ bacterial biostimulant or $(\mathbf{b})$ containing different levels of $\mathrm{NaCl}$ (for each interaction, bars with different letters are significantly different at $p<0.05$ according to the LSD test).

The bacterial biostimulant and salt stress also affected the leaf characteristics of lettuce plants (Table 3). Salt stress significantly reduced the number of leaves per plant $(-6.6 \%$ on average), whereas the bacterial inoculum positively affected this parameter in the first experiment increasing the number of leaves from 7.6 to 10.0. This positive effect was not recorded in the second cultivation season when the plants showed no significant difference between uninoculated and inoculated plants. The bacterial inoculum also significantly influenced the leaf morphology, enlarging leaf height, as shown by the increase in plant height, and leaf area (Table 3). The latter was higher during autumn $\left(49.1 \mathrm{~cm}^{2} \mathrm{leaf}^{-1} \mathrm{on}\right.$ average, $+14.5 \%$ than spring $)$ and due to the presence of PGPR in the nutrient solution $\left(51.1 \mathrm{~cm}^{2} \mathrm{leaf}^{-1}\right.$ on average, $+24.7 \%$ than uninoculated plants), whereas it was negatively affected by salt stress that reduced it by $19.7 \%$, compared to the unstressed plants. The total leaf area was negatively affected by salt stress, but the amplitude of this parameter and the reduction due to salinity, varied as a function of growing season and bacterial inoculant (Table 3, Figure 7). The lowest total leaf area of the unstressed plants was recorded in autumn-grown uninoculated plants $\left(354.6 \mathrm{~cm}^{2} \mathrm{plant}^{-1}\right)$ that showed a small reduction due to salt stress $(-8.4 \%)$. The highest leaf area per plant was measured in the same season in the inoculated plants grown without $\mathrm{NaCl}$ in the MNS $\left(640.0 \mathrm{~cm}^{2}\right.$ plant $\left.^{-1}\right)$; these plants reduced their leaf area under salt stress by $29.5 \%$, but despite this, they still resulted in a higher photosynthetic area than uninoculated plants. In spring, the plants grown without the bacterial biostimulant in the MNS were leafier and thus increased their total leaf area $\left(481.7 \mathrm{~cm}^{2}\right.$ plant $\left.{ }^{-1}\right)$ but were also more susceptible to the brackish nutrient solution, recording a reduction of $41.6 \%$ under salt stress. In the same season, the inoculated plants grown without salt stress reduced their leaf expansion compared to autumn, leading to a less wide total leaf area. When these plants were grown in brackish MNS, they reduced the plant leaf area by $17.3 \%$ but maintained a total leaf expansion $\left(476.9 \mathrm{~cm}^{2}\right.$ plant $\left.^{-1}\right)$ similar to that found in uninoculated unstressed plants.

The specific leaf area (SLA) recorded the main differences as a function of the growing season with higher leaf thickness in autumn than spring, whereas the increases due to the bacterial inoculum and the reductions due to salt stress were modest and showed little significance (Table 3). 
Table 3. Leaf characteristics of leaf lettuce plants grown during autumn and spring in nutrient solutions containing different levels of $\mathrm{NaCl}$ and bacterial biostimulant.

\begin{tabular}{|c|c|c|c|c|c|c|}
\hline \multicolumn{2}{|c|}{ Source of Variance } & $\begin{array}{l}\text { Number of } \\
\text { Leaves }\end{array}$ & 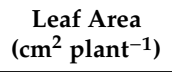 & $\begin{array}{l}\text { Leaf Area } \\
\left(\mathrm{cm}^{2} l e a f^{-1}\right)\end{array}$ & $\begin{array}{c}\text { SLA } \\
\left(\mathrm{cm}^{2} \mathrm{~g} \mathrm{DW}^{-1}\right)\end{array}$ & $\begin{array}{l}\text { Stomatal Conductance } \\
\left(\mathrm{mmol} \mathrm{m}^{2} \mathrm{~s}^{-1}\right)\end{array}$ \\
\hline \multicolumn{7}{|c|}{ Season } \\
\hline \multicolumn{2}{|c|}{ Autumn } & $\mathrm{z} 8.8$ & 442.6 & $49.1 \mathrm{a}$ & $904.7 \mathrm{a}$ & 617.3 \\
\hline & & 10.5 & 454.1 & $42.9 \mathrm{~b}$ & $662.8 \mathrm{~b}$ & 646.5 \\
\hline \multicolumn{7}{|c|}{ PGPR } \\
\hline \multicolumn{2}{|c|}{$-\mathrm{B}$} & 9.2 & 360.6 & $40.9 \mathrm{~b}$ & 774.9 & 550.8 \\
\hline & & 10.1 & 536.1 & 51.1a & 792.5 & 713.0 \\
\hline \multicolumn{7}{|c|}{$\mathrm{NaCl}(\mathrm{mM})$} \\
\hline \multicolumn{2}{|c|}{$\begin{array}{c}\mathrm{NaCl}(\mathrm{mM}) \\
0\end{array}$} & $10.0 \mathrm{a}$ & 513.2 & $51.0 \mathrm{a}$ & 798.4 & 648.9 \\
\hline \multicolumn{2}{|c|}{20} & $9.3 \mathrm{~b}$ & 383.5 & $41.0 \mathrm{~b}$ & 769.1 & 614.9 \\
\hline \multicolumn{7}{|c|}{ Season $\times$ PGPR } \\
\hline \multirow[t]{2}{*}{ Autumn } & $-B$ & $7.6 \mathrm{c}$ & 339.7 & 44.4 & 917.0 & $579.7 \mathrm{bc}$ \\
\hline & $+\mathrm{B}$ & $10.0 \mathrm{~b}$ & 545.5 & 53.8 & 892.3 & $654.8 \mathrm{~b}$ \\
\hline \multirow[t]{2}{*}{ Spring } & $-\mathrm{B}$ & $10.8 \mathrm{a}$ & 381.5 & 37.5 & 632.9 & $521.9 \mathrm{c}$ \\
\hline & $+\mathrm{B}$ & 10.1ab & 526.7 & 48.3 & 692.8 & 771.1a \\
\hline \multicolumn{7}{|c|}{ Season $\times \mathrm{NaCl}$} \\
\hline \multirow[t]{2}{*}{ Autumn } & 0 & 9.2 & 497.3 & $52.8 \mathrm{a}$ & 926.8 & 615.4 \\
\hline & 20 & 8.5 & 387.9 & $45.4 \mathrm{~b}$ & 882.5 & 619.1 \\
\hline \multirow{2}{*}{ Spring } & 0 & 10.8 & 529.1 & $49.2 \mathrm{a}$ & 670.0 & 682.4 \\
\hline & 20 & 10.1 & 379.1 & $36.6 \mathrm{c}$ & 655.6 & 610.7 \\
\hline \multicolumn{7}{|c|}{ PGPR $\times \mathrm{NaCl}$} \\
\hline \multirow[t]{2}{*}{$-B$} & 0 & 9.5 & 418.2 & 45.2 & 791.1 & $591.7 \mathrm{~b}$ \\
\hline & 20 & 9.0 & 303.0 & 36.6 & 758.8 & $509.9 \mathrm{c}$ \\
\hline \multirow[t]{2}{*}{$+\mathrm{B}$} & 0 & 10.5 & 608.2 & 56.8 & 805.7 & $706.0 \mathrm{a}$ \\
\hline \multirow{2}{*}{\multicolumn{7}{|c|}{ Significance $\mathrm{x}^{\mathrm{x}}$}} \\
\hline & & & & & & \\
\hline & & $* * *$ & ns & ** & $* * *$ & ns \\
\hline & & $* * *$ & $* * *$ & $* * *$ & ns & $* * *$ \\
\hline & & $* * *$ & $* * *$ & $* * *$ & ns & ns \\
\hline Season & & $* * *$ & ns & ns & ns & $* * *$ \\
\hline Season & & ns & ns & ns & ns & ns \\
\hline PGPR & & ns & ns & ns & ns & * \\
\hline Season $\times \mathrm{P}$ & $\times \mathrm{NaCl}$ & ns & $* * *$ & ns & ns & ns \\
\hline
\end{tabular}

${ }^{\mathrm{z}}$ Each value is the mean of 4 replicated samples of 20 plants each. For each factor, values in a column followed by the same letter are not significantly different, according to the LSD test. ${ }^{\times}$Significance: $n s=$ not significant; ${ }^{*}$ significant at $p<0.05 ;{ }^{* *}$ significant at $p<0.01 ;{ }^{* * *}$ significant at $p<0.001$.

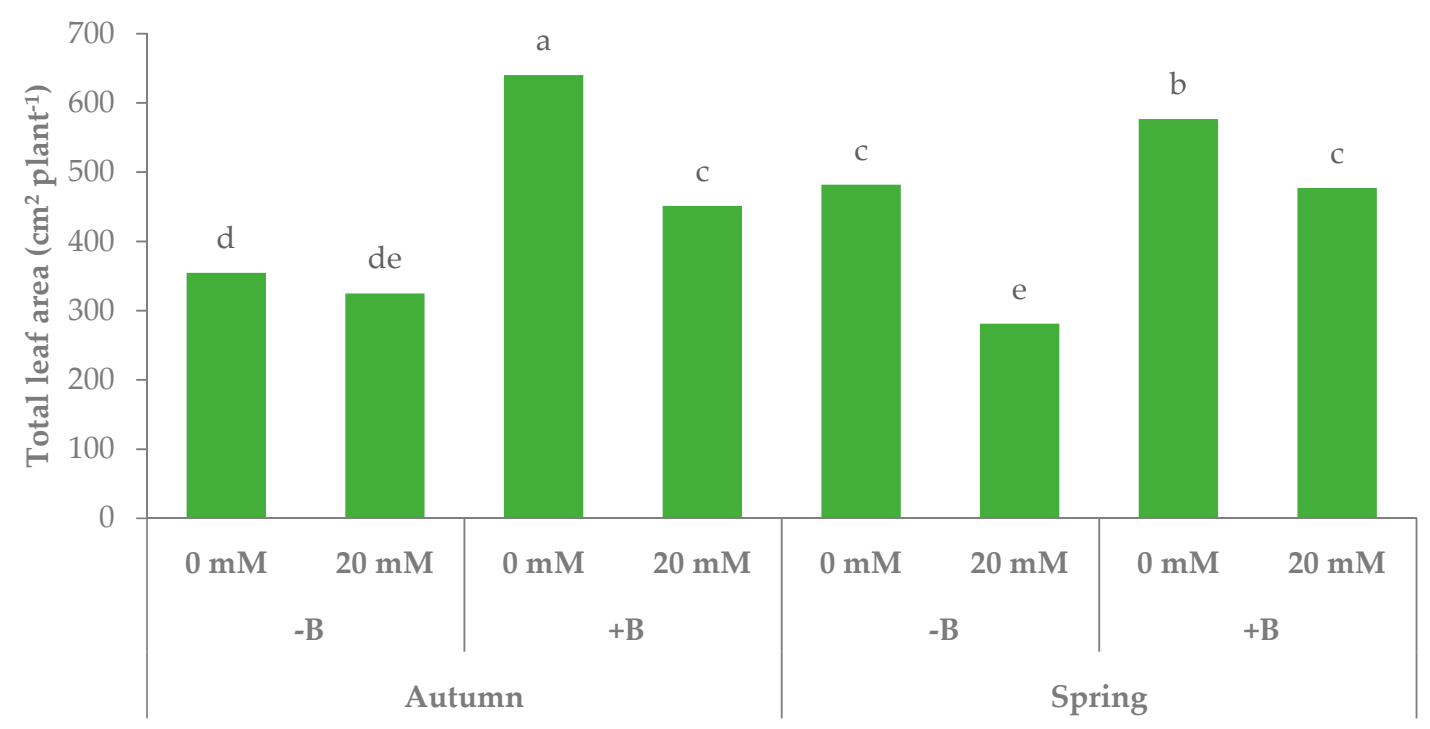

Figure 7. Total leaf area of leaf lettuce plants grown during autumn and spring in nutrient solutions containing different levels of $\mathrm{NaCl}$, with $(+\mathrm{B})$ or without $(-\mathrm{B})$ bacterial biostimulant (bars with different letters are significantly different at $p<0.05$, according to the LSD test).

Nutrient solutions added with the bacterial biostimulant and $\mathrm{NaCl}$ affected the leaf physiology as well as leaf morphology, as resulted by measuring the stomatal conductance (Table 3). The plants 
grown on nutrient solutions added with the bacterial biostimulant had a higher stomatal conductance, especially during spring, and retained this level of stomatal conductance even under salt stress

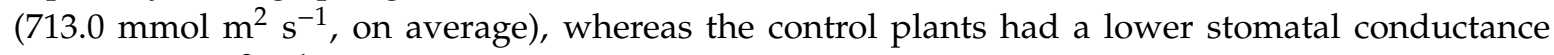
$\left(591.7 \mathrm{mmol} \mathrm{m}^{2} \mathrm{~s}^{-1}\right)$ that was further reduced by the salt stress $(-13.8 \%)$.

The leaves of lettuce plants changed their color characteristics mainly as a function of the growing season but also showed some change due to the bacterial inoculant in the spring cultivation (Table 4). In autumn, the leaves had higher $L^{*}$, chroma, and hue angle than in spring, when the bacterial biostimulant determined a slight reduction of $\mathrm{L}^{*}$ and a significant increase of hue angle.

Table 4. Leaf color and chemical characteristics of leaf lettuce plants grown during autumn and spring in nutrient solutions containing different levels of $\mathrm{NaCl}$ and bacterial biostimulant.

\begin{tabular}{|c|c|c|c|c|c|c|c|}
\hline \multicolumn{2}{|c|}{ Source of variance } & $L^{*}$ & Chroma & $\mathrm{Hue}^{\circ}$ & $\begin{array}{c}\text { TSS } \\
\left({ }^{\circ} \text { Brix }\right)\end{array}$ & $\begin{array}{c}\text { Ascorbic acid } \\
\left(\mathrm{mg} 100 \mathrm{~g}^{-1} \mathrm{FW}\right)\end{array}$ & $\begin{array}{c}\mathrm{N}-\mathrm{NO}_{3}{ }^{-} \\
\left(\mathrm{mg} \mathrm{kg}^{-1} \mathrm{FW}\right)\end{array}$ \\
\hline \multicolumn{8}{|c|}{ Season } \\
\hline \multicolumn{2}{|c|}{ Autumn } & $\mathrm{z} 47.6$ & $56.9 a$ & 123.1 & 2.7 & 116.7 & 3749.6 \\
\hline \multicolumn{2}{|c|}{ Spring } & 54.0 & $40.8 b$ & 122.1 & 4.0 & 69.1 & 1348.5 \\
\hline \multicolumn{8}{|c|}{ PGPR } \\
\hline \multicolumn{2}{|c|}{$-\mathrm{B}$} & 51.2 & 49.8 & 122.1 & 3.5 & 91.7 & 2495.2 \\
\hline \multicolumn{2}{|c|}{$+\mathrm{B}$} & 50.4 & 47.9 & 123.0 & 3.2 & 94.1 & 2602.9 \\
\hline \multicolumn{8}{|c|}{$\mathrm{NaCl}(\mathrm{mM})$} \\
\hline \multicolumn{2}{|c|}{0} & 50.9 & 50.0 & 122.5 & 3.1 & 91.1 & 2693.3 \\
\hline \multicolumn{2}{|c|}{20} & 50.7 & 47.7 & 122.7 & 3.6 & 94.8 & 2404.9 \\
\hline \multicolumn{8}{|c|}{ Season $\times$ PGPR } \\
\hline \multirow{2}{*}{ Autumn } & $-B$ & $46.7 \mathrm{~b}$ & 57.7 & $123.3 a$ & 2.7 & 118.8 & 3635.8 \\
\hline & $+\mathrm{B}$ & $48.6 \mathrm{~b}$ & 56.2 & $122.9 \mathrm{a}$ & 2.7 & 114.7 & 3863.3 \\
\hline \multirow[t]{2}{*}{ Spring } & $-B$ & $55.8 \mathrm{a}$ & 41.9 & $121.0 \mathrm{~b}$ & 4.2 & 64.6 & 1354.5 \\
\hline & $+\mathrm{B}$ & $52.3 \mathrm{ab}$ & 39.6 & $123.1 \mathrm{a}$ & 3.8 & 73.6 & 1342.5 \\
\hline \multicolumn{8}{|c|}{ Season $\times \mathrm{NaCl}$} \\
\hline \multirow{2}{*}{ Autumn } & 0 & 48.2 & 58.9 & 122.9 & 2.7 & 118.1 & $3715.8 \mathrm{a}$ \\
\hline & 20 & 47.0 & 55.0 & 123.3 & 2.8 & 115.3 & $3783.3 a$ \\
\hline \multirow[t]{2}{*}{ Spring } & 0 & 53.6 & 41.1 & 122.1 & 3.6 & 64.0 & $1670.7 \mathrm{a}$ \\
\hline & 20 & 54.5 & 40.5 & 122.1 & 4.4 & 74.2 & $1026.4 \mathrm{c}$ \\
\hline \multicolumn{8}{|c|}{ PGPR $\times \mathrm{NaCl}$} \\
\hline \multirow[t]{2}{*}{$-B$} & 0 & 51.5 & 50.4 & 122.1 & 3.3 & 92.6 & 2631.5 \\
\hline & 20 & 51.0 & 49.2 & 122.2 & 3.6 & 90.7 & 2358.9 \\
\hline \multirow[t]{2}{*}{$+B$} & 0 & 50.4 & 49.6 & 122.8 & 3.0 & 89.5 & 2755.0 \\
\hline & 20 & 50.5 & 46.2 & 123.2 & 3.5 & 98.8 & 2450.9 \\
\hline \multicolumn{8}{|c|}{ Significance $\mathrm{x}$} \\
\hline & & $* * *$ & $* * *$ & * & $* * *$ & $* * *$ & * \\
\hline & & ns & ns & * & ns & ns & ns \\
\hline & & ns & $\mathrm{ns}$ & $\mathrm{ns}$ & $* *$ & $\mathrm{~ns}$ & $*$ \\
\hline Seasor & SPR & $*$ & ns & $*$ & ns & $*$ & $\mathrm{~ns}$ \\
\hline Seaso & $\mathrm{aCl}$ & ns & ns & ns & $*$ & ns & $* *$ \\
\hline PGPI & $\mathrm{Cl}$ & ns & ns & $\mathrm{ns}$ & ns & ns & $\mathrm{ns}$ \\
\hline Season $\times 1$ & $\times \mathrm{NaCl}$ & ns & ns & ns & $* *$ & $*$ & $\mathrm{~ns}$ \\
\hline
\end{tabular}

${ }^{\mathrm{z}}$ Each value is the mean of 4 replicated samples of 20 plants each. For each factor, values in a column followed by the same letter are not significantly different, according to the LSD test. ${ }^{x}$ Significance: $n s=$ not significant; ** significant at $p<0.05 ;{ }^{* *}$ significant at $p<0.01 ;{ }^{* * *}$ significant at $p<0.001$.

The quality of the leaves of leaf lettuce, which represent the edible part of this plant, was evaluated at the end of each growing season, by measuring the total soluble solids (TSS) and nitrate and ascorbic acid content (Table 4). TSS showed small variations during the first growing season ( $2.7^{\circ}$ Brix on average), whereas in spring it increased up to $4.3^{\circ}$ Brix on average for uninoculated plants and inoculated stressed plants (Figure 8). On the contrary, the ascorbic acid content was higher in autumn (116.7 mg $100 \mathrm{~g}^{-1} \mathrm{FW}$ ) than in spring, when it almost halved in uninoculated plants and inoculated unstressed plants (63.6 mg $100 \mathrm{~g}^{-1} \mathrm{FW}$ ) and increased up to $85.6 \mathrm{mg} 100 \mathrm{~g}^{-1} \mathrm{FW}$ in the inoculated stressed plants (Figure 9). Lettuce leaves accumulated a higher amount of nitrate in autumn 
(3749.6 $\mathrm{mg} \mathrm{kg}^{-1} \mathrm{FW}$ on average) when the experimental treatments did not influence this parameter, whereas in spring the nitrate content of lettuce leaves dropped down to $1670.7 \mathrm{mg} \mathrm{kg}^{-1} \mathrm{FW}$ on average, in the plants grown without $\mathrm{NaCl}$ in the MNS, and was further reduced by salt stress $(-38.6 \%$ ) (Table 4$)$.

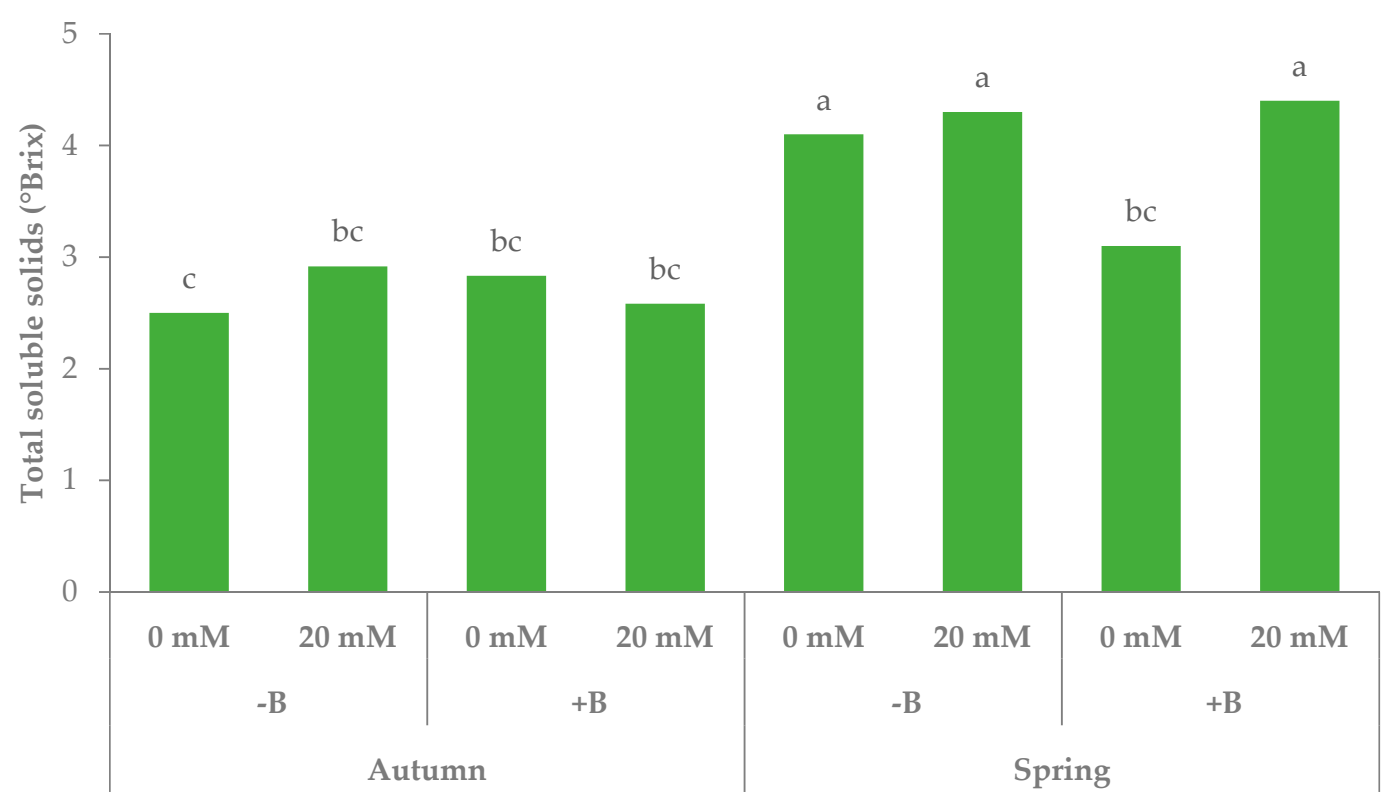

Figure 8. Total soluble solids of the leaf of lettuce plants grown during autumn and spring in nutrient solutions containing different levels of $\mathrm{NaCl}$ and with $(+\mathrm{B})$ or without $(-\mathrm{B})$ bacterial biostimulant (bars with different letters are significantly different at $p<0.05$, according to the LSD test).

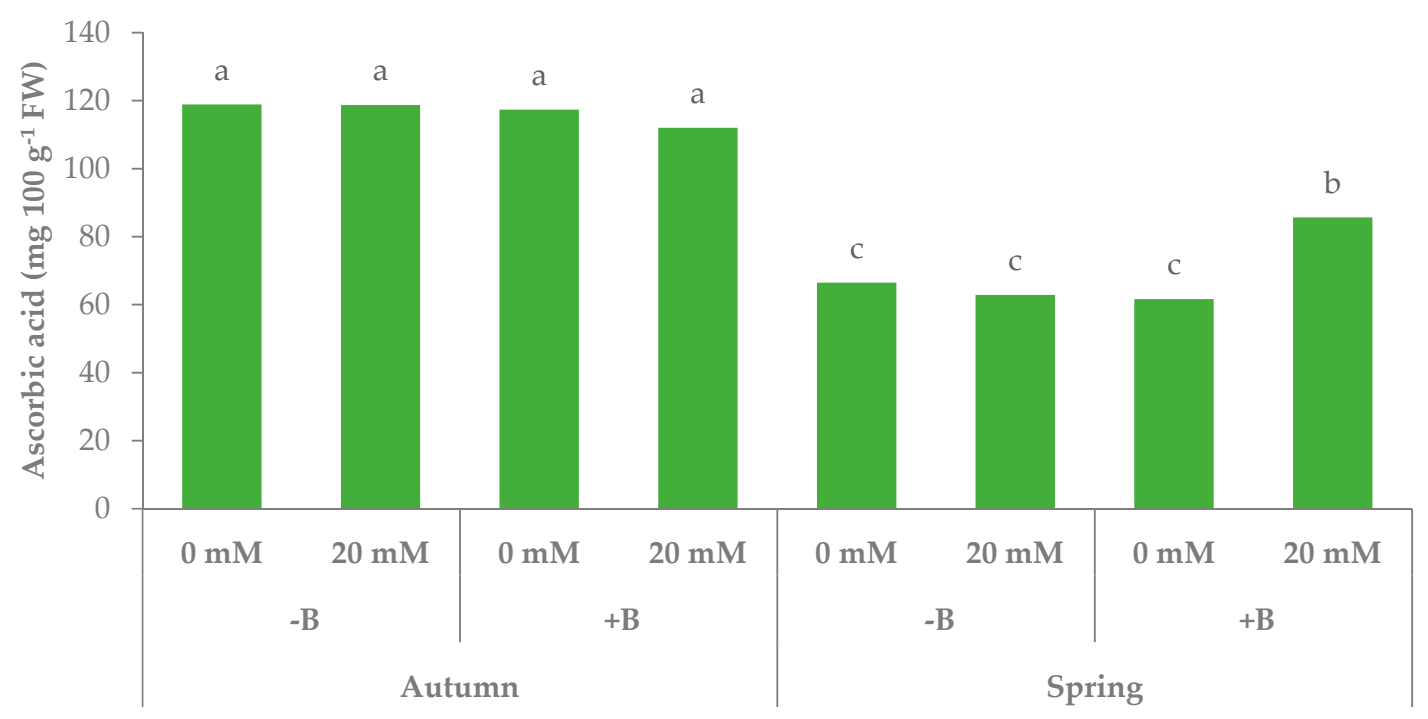

Figure 9. Ascorbic acid content of the leaf of lettuce plants grown during autumn and spring in nutrient solutions containing different levels of $\mathrm{NaCl}$ and with $(+\mathrm{B})$ or without $(-\mathrm{B})$ bacterial biostimulant (bars'with different letters are significantly different at $p<0.05$, according to the LSD test).

\subsection{Principal Components Analysis}

The principal component analysis (PCA) detected four principal components (PCs) with eigenvalues higher than 1 (Table 5), assessing $57.91 \%, 22.11 \%, 7.33 \%$, and $5.60 \%$ of the total variance, respectively. Thus, the initial 26 variables could be represented by a linear combination of four PCs, which explained $90.94 \%$ of the total variance. PC1 was mainly related to plant height, whole plant fresh weight (FW), shoot (S) FW, roots (R) FW, R/S FW, whole plant DW, shoot DW, roots DW, R/S DW, 
crop yield, leaf yield, WUE, NUE, leaf area, SLA, leaf color components, TSS, ascorbic acid, and nitrate content. PC2 was related to shoot FW, R/S FW, R/S DW, crop yield, leaf yield, leaf number, plant area, stomatal conductance, and ascorbic acid content. PC3 was related to plant dry matter percentage and minimal processing yield. PC4 was related to plant dry matter percentage and hue angle (Table 5). Projecting the original variables on the plane of the two main PCs could betoken such a relationship, as shown in the plot of loadings (Figure 10a). The discrimination of the experimental factors applied to leaf lettuce plants could be studied in the plot of scores (Figure 10b), where two main clusters could be visibly distinguished. The scores of lettuce plants grown in the autumn season and those grown in spring in nutrient solutions without $\mathrm{NaCl}$ and inoculated with the bacterial biostimulant were located in the positive part of the PC1 axis, and were clearly separated from the other spring treatments located in the negative part of the PC1 axis.

Table 5. Correlation of variables to the factors of the principal components analysis (PCA) based on factor loadings.

\begin{tabular}{ccccc}
\hline Variable & PC1 & PC2 & PC3 & PC4 \\
\hline Plant height & $\mathbf{0 . 9 5 3}$ & 0.080 & -0.234 & -0.048 \\
Whole plant FW & $\mathbf{0 . 9 4 2}$ & 0.312 & 0.039 & 0.017 \\
Shoot FW & $\mathbf{0 . 7 6 7}$ & $\mathbf{0 . 6 1 9}$ & -0.025 & -0.022 \\
Root FW & $\mathbf{0 . 9 3 2}$ & -0.277 & 0.124 & 0.072 \\
R/S FW & $\mathbf{0 . 7 8 7}$ & $\mathbf{- 0 . 5 4 5}$ & 0.212 & -0.005 \\
Whole plant DW & $\mathbf{0 . 8 7 0}$ & 0.353 & 0.285 & 0.168 \\
Shoot DW & $\mathbf{0 . 7 1 8}$ & $\mathbf{0 . 6 1 7}$ & 0.212 & 0.143 \\
Roots DW & $\mathbf{0 . 8 2 6}$ & -0.263 & 0.294 & 0.170 \\
S/R DW & $\mathbf{0 . 6 7 1}$ & $\mathbf{- 0 . 5 0 8}$ & 0.291 & 0.074 \\
Plant DM & -0.274 & -0.157 & $\mathbf{0 . 6 1 9}$ & $\mathbf{0 . 5 6 8}$ \\
Crop Yield & $\mathbf{0 . 7 5 7}$ & $\mathbf{0 . 6 2 4}$ & -0.175 & -0.014 \\
Minimal processing Yield & -0.438 & -0.379 & $\mathbf{0 . 6 1 1}$ & -0.368 \\
Leaf Yield & $\mathbf{0 . 7 3 7}$ & $\mathbf{0 . 6 3 4}$ & -0.039 & -0.111 \\
WUE & $\mathbf{0 . 8 3 5}$ & 0.150 & 0.378 & 0.218 \\
NUE & $\mathbf{0 . 9 0 7}$ & -0.350 & 0.116 & 0.183 \\
Leaf No. & -0.414 & $\mathbf{0 . 7 0 3}$ & 0.023 & 0.409 \\
Plant area & 0.427 & $\mathbf{0 . 8 0 4}$ & 0.013 & 0.000 \\
Leaf area & $\mathbf{0 . 7 9 6}$ & $\mathbf{0 . 5 6 1}$ & -0.136 & 0.000 \\
SLA & $\mathbf{0 . 8 6 3}$ & -0.398 & -0.268 & -0.004 \\
L & 0.381 & $\mathbf{0 . 6 4 7}$ & 0.314 & -0.499 \\
Stomatal conductance & $\mathbf{- 0 . 8 6 3}$ & 0.413 & -0.039 & 0.214 \\
Chroma & $\mathbf{0 . 7 4 8}$ & -0.499 & -0.362 & 0.148 \\
Hue angle & $\mathbf{0 . 7 2 6}$ & -0.089 & 0.320 & $\mathbf{- 0 . 5 4 1}$ \\
SSC & $\mathbf{- 0 . 9 1 3}$ & 0.152 & 0.213 & -0.110 \\
Ascorbic acid & $\mathbf{0 . 7 6 4}$ & $\mathbf{- 0 . 5 4 4}$ & -0.182 & -0.098 \\
Nitrate content & $\mathbf{0 . 8 6 5}$ & -0.414 & -0.205 & 0.101 \\
\hline V & & & & \\
\hline
\end{tabular}

Values in bold within the same factor indicate the variable with the largest correlation.

The response of lettuce varied in the two growing seasons, as it was observed mainly an increase of the PC2 values due to the bacterial biostimulant and a decrease of the PC2 values due to salt stress in the autumn cultivation, whereas there were also increases or reduction due to bacterial biostimulant and salt stress, respectively, for the PC1 values in the spring cultivation.

Combining the data from the plot of loadings and scores, it could be concluded that the experimental factor influenced leaf lettuce in different ways (Figure 10a,b). The autumn cultivation was related to all parameters positively related to PC1. The presence of the bacterial biostimulant in the nutrient solution was positively related mainly to PC2 in spring, and to both PC1 and PC2 in autumn. The addition of $\mathrm{NaCl}$ to the MNS was negatively related to PC2 in autumn and to PC1 and PC2 in spring. 

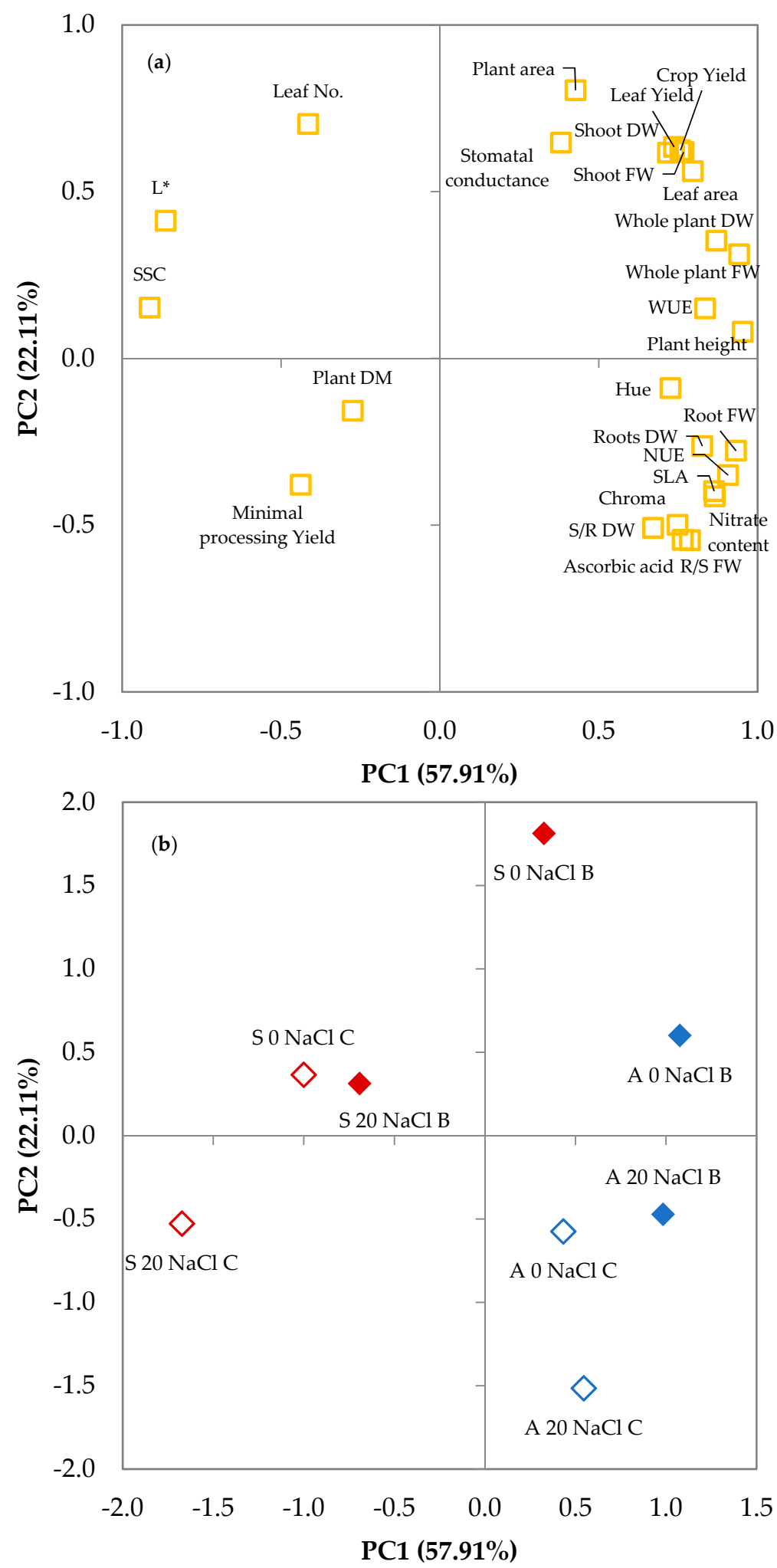

Figure 10. Plot of (a) loadings (morphophysiological and quality characteristics of leaf lettuce plants) and (b) scores (trials) formed by the two principal components from the Principal Component Analysis (PCA). A: autumn cultivation (blue color); S: spring cultivation (red color); $0 \mathrm{NaCl}, 20 \mathrm{NaCl}: \mathrm{mM}$ of $\mathrm{NaCl}$ in the nutrient solution; $\mathrm{C}$ : nutrient solutions not inoculated with the bacterial biostimulant (empty symbol); and B: nutrient solutions inoculated with the bacterial biostimulant (full symbol). 


\section{Discussion}

Poor quality water due to high salt content is one of the most important problems worldwide for vegetable growers, as it causes reductions of crop yield or even makes it very difficult to grow sensitive crops. Among leafy vegetables, lettuce is one of the most used for salads and can be classified as a relatively salt-sensitive crop $[5,34]$. The tolerance of vegetable crops to salinity is generally defined as the ability of plants to hold out against the negative effects of high salt concentration, without significant detrimental effects [5]. These effects should be considered mainly on the portion of the plant to be marketed [35]. Thus, the measurement of salt tolerance in lettuce plants should be based mainly on yield decline caused by shoot fresh weight reduction, or leaf fresh weight decrease, in the case of leaf lettuce. $\mathrm{Xu}$ and Mou [34] found that leaf lettuce varieties can suffer shoot fresh mass reduction of up to about $60 \%$, under salt stress conditions, due to fertigation with a nutrient solution with an EC of $8.4 \mathrm{mS} \mathrm{cm}^{-1}$. In our experiments, we found a lower effect of salt stress, which on average determined a reduction by $17.3 \%$ of shoot fresh weight for uninoculated plants, probably due to a lower EC $\left(4.4 \mathrm{mS} \mathrm{cm}^{-1}\right)$ of the brackish nutrient solution. Vegetables grown under salt stress usually show a visible reduction of the growth rate, smaller leaves and fruits, shorter plants, and modification of other morphological traits that end in the reduction of plant biomass [2,5]. These modifications were also found in leaf lettuce [16] and mainly consisted of the reduction of plant and leaf development (shorter plants and smaller leaves) and plant water content. The higher dry matter content could be linked to the increased osmotic stress caused by the high salt concentration of the MNS, which might limit water uptake and cause changes in plant metabolism and nutrient uptake. The reduced availability of the nutrients in the MNS due to salinity can lead to a severe reduction of plant growth $[5,36]$. This reduction induced by the exposure to salt stress was mainly recorded in terms of shoot fresh biomass and was mostly due to osmotic effects and changes in the water status of the plants, as shown by the low effect of salinity on the accumulation of dry biomass in the shoots.

The sensitivity of leaf lettuce plants to salinity showed some differences according to the growing seasons, which also influenced the growth potential of leaf lettuce plants. There was a significant difference in the reduction in shoot fresh weight, under salt stress recorded in leaf lettuce plants grown in autumn or spring. Control plants were more tolerant to salinity in autumn than in spring, as shown by the greater reductions of shoot fresh weight and crop and leaf yield, which were $-11.3 \%,-19.6 \%$, and $-7.6 \%$ in autumn and $-23.4 \%,-27.5 \%$, and $-27.9 \%$ in spring, respectively. The salt tolerance threshold of vegetable crops and the severity of salt stress effects might vary greatly among species or even among varieties within a species and are very sensitive to environmental conditions [5]. Among the environmental factors, temperature, wind, relative humidity, light, and atmosphere composition might significantly affect plant growth and interact with salinity [37]. The sensitivity to salinity increases in most crops under high temperatures and dry conditions [5,37], which might also negatively affect $\mathrm{CO}_{2}$ assimilation and the efficiency of the photosynthetic process, determining a reduction of growth and yield. This could explain the reduction in plant growth and the lower salt tolerance of leaf lettuce recorded in spring cultivation. Even if the average daily temperatures were similar in autumn and spring cultivation periods, the analysis of average hourly temperatures and relative humidity showed some important climatic differences. The differential between hourly air temperatures in autumn and spring was greater than $1{ }^{\circ} \mathrm{C}$ for five hours, every day on average, and reached $4{ }^{\circ} \mathrm{C}$ during the day. The mean hourly relative humidity was $10.8 \%$ lower in spring than autumn on average and the differential between the values recorded in spring and autumn overcame $-10 \%$ for ten hours daily and $-25 \%$ for two hours daily. Thus, during spring, there was a higher vapor-pressure deficit (VPD) that probably increased the stomatal resistance and enhanced the osmotic stress determined by salinity. This hypothesis could be confirmed by the modifications of stomatal conductance and total leaf area that were significantly lowered during spring, especially under salt stress $(-23.8 \%$ and $-41.6 \%$, respectively). Osmotic stress can strongly reduce stomatal conductance [38], thus also decreasing photosynthesis and plant growth [39]. The decrease in water availability during spring due to the interaction between VPD and salinity, probably limited leaf expansion and consequently 
determined the reduction of light interception and photosynthesis more than that in the autumn experiment [40]. The effects of the salinity level used in the present study carried out with a floating system, were probably mainly due to osmotic stress, although the effects of ionic stress could not be fully separated [6].

Leafy vegetables tend to accumulate high levels of nitrates in the leaves, thus limiting their nutritional quality, as nitrates can be negative to human health [41-43]. Moreover, lettuce can lose marketability if its nitrate content overcomes the thresholds imposed by EU regulations [44]. The lower light duration and intensity during autumn, probably limited the activity of nitrate reductase and increased the nitrate content of lettuce leaves up to $3749.6 \mathrm{mg} \mathrm{kg}^{-1} \mathrm{FW}$. This value, although high, was well below the thresholds imposed by EU regulations, for lettuce plants grown under protected cultivation in autumn [44]. The more favorable light condition recorded during spring increased the nitrate reductase activity [45] and almost halved the leaf nitrate content, which was further reduced under salt stress condition. The salinity of nutrient solutions can make the absorption of essential cations and anions like $\mathrm{K}^{+}$and $\mathrm{NO}_{3}{ }^{-}$problematic $[46,47]$. Moreover, osmotic stress can determine a reduction of water uptake, thus also reducing nitrate uptake. These effects on nitrate uptake determined by moderate salt stress could help in improving the nutritional quality and market value of some leafy vegetables [16], as found in our spring experiment.

Leaf lettuce showed a reduction by $40.8 \%$ of the ascorbic acid content, on average, during spring cultivation, as compared to autumn cultivation. The concentration of vitamin $\mathrm{C}$ in some fruits and vegetables seems to be related to nitrogen metabolism, as high nitrogen availability often corresponds to lower vitamin $C$ content, even if variations could occur according to species, climate, and other factors $[48,49]$. Thus, the more active nitrogen metabolism recorded in spring and revealed by the lower nitrate accumulation could have limited the ascorbic acid content in the leaves.

The inhibition of lettuce plant growth due to salt stress was significantly alleviated by the addition of the bacterial biostimulant to the MNS. This had a positive effect on plant growth and fresh and dry biomass accumulation of the unstressed lettuce in both cultivation seasons. It also maintained this positive effect in brackish MNS, with similar or even significantly higher plant growth (plant height, biomass accumulation, leaf number, leaf area) than unstressed control plants. The positive effects of PGPR on vegetable growth are well-known [50], but only a few studies focused on PGPR application in hydroponic culture [51-53]. PGPR can exert their effect on vegetables in different mechanisms that could vary according to bacteria species [54]. Some of these mechanisms determine changes in hormonal content, production of volatile compounds, increased nutrient availability or enhanced tolerance to abiotic stress [55]. In our study, the bacterial biostimulant showed a clear growth-promoting activity on leaf lettuce plants, in the absence of salt stress in both seasons, but to a greater extent during spring. The percentage increase of shoot and root fresh weight, shoot dry weight, yield, WUE, and NUE, due to bacterial biostimulant in the unstressed plants, almost doubled in spring compared to autumn, mainly because inoculated plants maintained higher values in both seasons, whereas control plants reduced their growth in spring. A positive effect was also recorded on leaf area and stomatal conductance; both these enhancements could have increased light interception and $\mathrm{CO}_{2}$ assimilation, as the decrease in intercellular $\mathrm{CO}_{2}$ partial pressure increases the net photosynthetic rate [56]. Improvements in growth and yield were widely reported in many crops, as a consequence of inoculation with PGPR $[50,57,58]$. The species belonging to the genera Pseudomonas and Bacillus were most extensively studied and used for commercial products, among the bacteria that showed growth-promoting activity [59]. Many species of Bacillus and Paenibacillus, like those present in Bactor $^{513}$, can exert plant growth-promoting activity through different mechanisms like the production of growth-promoting phytohormones or inhibition of plant ethylene synthesis, nitrogen fixation, phosphate solubilization and mobilization, production of siderophore and antibiotics, and induction of systemic resistance to pathogens in plants [60,61]. Bacillus strains application proved to be effective in enhancing plant growth crops under greenhouse or field conditions for several vegetable crops like broccoli, cucumber, pepper, tomato, and lettuce $[50,62,63]$. The inoculation of lettuce plants with 
Bacillus subtilis can determine the increase of the cytokinin content of shoots and roots, and influence the content of abscisic acid (ABA) and indole acetic acid (IAA) [64]. The hormonal substances produced by PGPR can stimulate endogenous hormones and can play a key role in improving salt tolerance [65]. These modifications were associated with an increase in shoot and root weight of approximately $30 \%$, which was in agreement with the growth promotion determined by the bacterial biostimulant used in our study. Other Bacillus spp. such as B. velezensis, B. amyloliquefaciens, and B. methylotrophicus showed to increase the plant growth and food values through different mechanisms when applied to lettuce plants [52,66-68].

Bacillus spp. and other PGPR were also studied and applied to increase the tolerance to abiotic stresses of many crops [69-71]. Besides promoting plant growth, PGPR also have the ability to enhance crop tolerance to salinity $[20,25]$. It was reported that vigorous plants can better deal with salinity, through the increase of salt tolerance threshold or by procrastinating its onset [72]. The application of PGPR can effectively increase plant growth and vigor, as shown in our work, and can affect plant metabolism, as previously described, thus aiding plants to better cope with salt stress. The ability of PGPR to enhance crop tolerance to salinity and other abiotic stresses could be determined by various mechanisms involving changes in phytohormone content, antioxidant defense, osmolyte production, ACC (1-aminocyclopropane-1-carboxylate) deaminase activity, and biofilm formation [73-77].

The bacterial biostimulant containing Bacillus spp. added to the nutrient solution successfully mitigated salt stress and improved the salt tolerance of leaf lettuce plants grown on floating panels. Almost all morphological, physiological, and yield parameters evaluated in the plants grown under salt stress and inoculated with the bacterial biostimulant were similar or even higher than those recorded in control unstressed plants in both growing seasons. Hence, the negative effect of salinity was fully overcome, thanks to the PGPR added to the MNS.

Under salt stress, the plants are forced to reduce the stomatal opening, to compensate for the reduced ability to take up water. However, this results in reduced volume of air exchanged with the environment and intercellular $\mathrm{CO}_{2}$ concentration, leading to lower photosynthetic rates and limited growth [78]. Plants supplemented with the bacterial biostimulant showed a higher stomatal conductance than the control plants, under salt stress, and this could be one of the beneficial mechanisms of salt tolerance induced by the PGPR. Ethylene content increases in plants under abiotic stress and it negatively affects photosynthesis and stomatal conductance [79]. Some Bacillus spp., such as Bacillus amyloliquefaciens, have the ability to control ethylene formation in roots, through the enzyme ACC-deaminase [80,81]. This enzyme converts ACC, the immediate precursor of ethylene synthesis in plants, to ammonia and $\alpha$-ketobutyrate [82]. Thus, ACC exuded from plant roots is metabolized by PGPR and the efflux from roots decreases ACC and ethylene concentration, resulting in increased root growth and development, and lower translocation to leaves. This, together with the IAA produced by rhizobacteria, could explain the greater root biomass under salt stress of inoculated plants than control plants, and the significant improvement in stomatal conductance of the plants treated with ACC-deaminase producing PGPR [82].

Plants react to salt stress by producing reactive oxygen species (ROS), which functions as a signal during salt stress and simultaneously damages root and shoot tissues by altering the enzyme, cell wall, and membrane function. ROS might accumulate during salt stress, inducing an increase of superoxide dismutase (SOD) and ascorbate peroxidase, and the use of ascorbic acid and glutathione, to prevent oxidative damage in plants that determine the reduction of antioxidant and ascorbic acid content in the leaves. On the contrary, we found an increase in the ascorbic acid content during spring, in the inoculated plants subjected to salt stress. PGPR might have a role in ROS management by improving enzymatic and nonenzymatic antioxidant activities [83], and this could have allowed inoculated stressed plants to improve ascorbic acid metabolism.

As shown before, the severity of salt stress effects might vary greatly according to species and it might be alleviated or accentuated by climatic or agronomic factors $[5,9,16,84,85]$. The differences in the modification to salt tolerance due to cultivation season and bacterial biostimulant were well-shown 
by the PCA analysis that underlined the different growth potential of lettuce plants and their different responses to salt stress during autumn and spring. It also showed that the inoculation of the MNS with the bacterial biostimulant, counterbalanced the salinity, acting on different plant adaptation systems. Moreover, the effects of salinity and bacterial biostimulant had a different extent in the cultivation seasons, thus, confirming that the response to these factors might vary according to environmental conditions $[16,59,86]$.

\section{Conclusions}

Leaf lettuce plants grown in a hydroponic floating system with a brackish mineral nutrient solution suffered significant reductions of growth and yield and were more sensitive to salinity in spring than autumn. The initial inoculation of the MNS with the bacterial biostimulant was successful in promoting vigorous plant growth in both seasons and allowed substantial counterbalancing of the salt stress, by improving various morphological and physiological traits, such as biomass accumulation, leaf expansion, stomatal conductance, WUE, NUE, etc.. Thus, the use of the bacterial biostimulant with Bacillus spp. in hydroponic cultivation of leaf lettuce, proved to be a sustainable mean to increase crop yield and to alleviate salt stress when difficulties in finding water of good quality makes the use of brackish water a necessity.

Author Contributions: Conceptualization, A.M. (Alessandra Moncada), F.V. and A.M. (Alessandro Miceli); Data curation, A.M. (Alessandra Moncada), F.V. and A.M. (Alessandro Miceli); Formal analysis, A.M. (Alessandra Moncada) and A.M. (Alessandro Miceli); Investigation, A.M. (Alessandra Moncada), F.V. and A.M. (Alessandro Miceli); Methodology, A.M. (Alessandra Moncada), F.V. and A.M. (Alessandro Miceli); Supervision, A.M. (Alessandro Miceli); Validation, F.V. and A.M. (Alessandro Miceli); Visualization, A.M. (Alessandro Miceli); Writing - original draft, A.M. (Alessandra Moncada) and A.M. (Alessandro Miceli); Writing-review \& editing, F.V. and A.M. (Alessandro Miceli). All authors have read and agreed to the published version of the manuscript.

Funding: This research received no external funding.

Acknowledgments: The authors would like to thank Marina Di Simone, Monia Gnoffo, and Roberta Lo Nardo for their precious help and support.

Conflicts of Interest: The authors declare no conflict of interest.

\section{References}

1. Cassman, K.G.; Dobermann, A.; Walters, D.T.; Yang, H. Meeting Cereal Demand While Protecting Natural Resources and Improving Environmental Quality. Annu. Rev. Environ. Resour. 2003, 28, 315-358. [CrossRef]

2. Shahbaz, M.; Ashraf, M.; Al-Qurainy, F.; Harris, P.J.C. Salt Tolerance in Selected Vegetable Crops. Crit. Rev. Plant Sci. 2012, 31, 303-320. [CrossRef]

3. Shahbaz, M.; Ashraf, M. Improving Salinity Tolerance in Cereals. Crit. Rev. Plant Sci. 2013, 32, $237-249$. [CrossRef]

4. Yamaguchi, T.; Blumwald, E. Developing salt-tolerant crop plants: Challenges and opportunities. Trends Plant Sci. 2005, 10, 615-620. [CrossRef] [PubMed]

5. Shannon, M.C.; Grieve, C.M. Tolerance of vegetable crops to salinity. Sci. Hortic. 1998, 78, 5-38. [CrossRef]

6. Munns, R.; Tester, M. Mechanisms of Salinity Tolerance. Annu. Rev. Plant Biol. 2008, 59, 651-681. [CrossRef] [PubMed]

7. Läuchli, A.; Grattan, S.R. Plant Responses to Saline and Sodic Conditions. In Agricultural Salinity Assessment and Management; American Society of Civil Engineers: Reston, VA, USA, 2011; pp. 169-205. ISBN 9780784476482.

8. Zahir, Z.A.; Munir, A.; Asghar, H.N.; Shaharoona, B.; Arshad, M. Effectiveness of Rhizobacteria Containing ACC Deaminase for Growth Promotion of Peas (Pisum sativum) Under Drought Conditions. J. Microbiol. Biotechnol. 2008, 18, 958-963.

9. Miceli, A.; Moncada, A.; D'Anna, F. Effect of salt stress in lettuce cultivation. Acta Hortic. 2003, 609, 371-375. [CrossRef]

10. Moncada, A.; Miceli, A.; D'Anna, F. Evaluation of strawberry cultivars in soilless cultivation in sicily. Acta Hortic. 2008, 801, 1121-1127. [CrossRef] 
11. Settanni, L.; Miceli, A.; Francesca, N.; Cruciata, M.; Moschetti, G. Microbiological investigation of Raphanus sativus L. grown hydroponically in nutrient solutions contaminated with spoilage and pathogenic bacteria. Int. J. Food Microbiol. 2013, 160, 344-352. [CrossRef]

12. Moncada, A.; Miceli, A.; Sabatino, L.; Iapichino, G.; D'Anna, F.; Vetrano, F. Effect of molybdenum rate on yield and quality of lettuce, escarole, and curly endive grown in a floating system. Agronomy 2018, 8, 171. [CrossRef]

13. D'Anna, F.; Miceli, A.; Vetrano, F. First results of floating system cultivation of Eruca sativa L. Acta Hortic. 2003, 609, 361-364. [CrossRef]

14. Miceli, A.; Moncada, A.; Vetrano, F.; D'Anna, F. First results on yield and quality response of Basil (Ocimum basilicum L.) grown in a floating system. Acta Hortic. 2003, 609, 377-381. [CrossRef]

15. Moncada, A.; Miceli, A.; Vetrano, F. Use of plant growth-promoting rhizobacteria (PGPR) and organic fertilization for soilless cultivation of basil. Sci. Hortic. 2020, in press. [CrossRef]

16. Vetrano, F.; Moncada, A.; Miceli, A. Use of Gibberellic Acid to Increase the Salt Tolerance of Leaf Lettuce and Rocket Grown in a Floating System. Agronomy 2020, 10, 505. [CrossRef]

17. Mariani, L.; Ferrante, A. Agronomic management for enhancing plant tolerance to abiotic stresses-drought, salinity, hypoxia, and lodging. Horticulturae 2017, 3, 52. [CrossRef]

18. Dajic, Z. Salt stress. In Physiology and Molecular Biology of Stress Tolerance in Plants; Rao, K., Raghavendra, A., Eddy, K., Eds.; Kluwer Academic Publishers: Dordrecht, The Netherlands, 2006; pp. 41-99.

19. Wang, Y.; Mopper, S.; Hasenstein, K.H. Effects of salinity on endogenous ABA, IAA, JA, and SA in Iris hexagona. J. Chem. Ecol. 2001, 27, 327-342. [CrossRef]

20. Egamberdieva, D. Alleviation of salt stress by plant growth regulators and IAA producing bacteria in wheat. Acta Physiol. Plant. 2009, 31, 861-864. [CrossRef]

21. Tate, R.L. Phytohormones in Soils: Microbial Production and Function. Soil Sci. 1996, 161, 202. [CrossRef]

22. Frankenberger, W.T., Jr.; Arshad, M. Phytohormones in Soils Microbial Production \& Function; CRC Press: Boca Raton, FL, USA, 2020; ISBN 1000723607.

23. Turan, M.; Yildirim, E.; Kitir, N.; Unek, C.; Nikerel, E.; Ozdemir, B.S.; Güneş, A.; Mokhtari, N.E.P. Beneficial role of plant growth-promoting bacteria in vegetable production under abiotic stress. In Microbial Strategies for Vegetable Production; Zaidi, A., Khan, M.S., Eds.; Springer International Publishing: Berlin/Heidelberg, Germany, 2017; pp. 151-166.

24. Ekinci, M.; Turan, M.; Yildirim, E.; Güneş, A.; Kotan, R.; Dursun, A. Effect of plant growth promoting rhizobacteria on growth, nutrient, organic acid, amino acid and hormone content of cauliflower (Brassica oleracea L. var. botrytis) transplants. Acta Sci Pol Hortorum Cult. 2014, 13, 71-85.

25. Numan, M.; Bashir, S.; Khan, Y.; Mumtaz, R.; Shinwari, Z.K.; Khan, A.L.; Khan, A.; AL-Harrasi, A. Plant growth promoting bacteria as an alternative strategy for salt tolerance in plants: A review. Microbiol. Res. 2018, 209, 21-32. [CrossRef] [PubMed]

26. Shrivastava, P.; Kumar, R. Soil salinity: A serious environmental issue and plant growth promoting bacteria as one of the tools for its alleviation. Saudi J. Biol. Sci. 2015, 22, 123-131. [CrossRef] [PubMed]

27. Sonneveld, C.; Voogt, W. Plant Nutrition of Greenhouse Crops; Springer: Dordrecht, The Netherlands, 2009; ISBN 978-90-481-2531-9.

28. Miceli, A.; Moncada, A.; Sabatino, L.; Vetrano, F. Effect of Gibberellic Acid on Growth, Yield, and Quality of Leaf Lettuce and Rocket Grown in a Floating System. Agronomy 2019, 9, 382. [CrossRef]

29. Fageria, N.K.; Baligar, V.C.; Li, Y.C. The role of nutrient efficient plants in improving crop yields in the twenty first century. J. Plant Nutr. 2008, 31, 1121-1157. [CrossRef]

30. McGuire, R.G. Reporting of objective color measurements. HortScience 1992, 27, 1254-1255. [CrossRef]

31. Rodrigo, M.C.; Ramos, C. Nitrate sap analysis as a tool to assess nitrogen nutrition in artichoke. In Proceedings of the VI International Symposium on Artichoke, Cardoon and Their Wild Relatives 730, Lorca, Spain, 28-31 March 2006; pp. 251-256.

32. Miceli, A.; Miceli, C. Effect of nitrogen fertilization on the quality of swiss chard at harvest and during storage as minimally processed produce. J. Food Qual. 2014, 37, 125-134. [CrossRef]

33. Caracciolo, G.; D'Anna, E.; Moncada, A.; D'Anna, F. Evaluation of the quality and antioxidant capacity of woodland strawberry biotypes in Sicily. J. Food Agric. Environ. 2013, 11, 522-525.

34. Xu, C.; Mou, B. Evaluation of Lettuce Genotypes for Salinity Tolerance. HortScience 2015, 50, 1441-1446. [CrossRef] 
35. Lunin, J.; Gallatin, M.H.; Batchelder, A.R. Saline Irrigation of Several Vegetable Crops at Various Growth Stages. I. Effect on Yields 1. Agron. J. 1963, 55, 107-110. [CrossRef]

36. Grieve, C.M.; Grattan, S.R.; Maas, E. V Plant salt tolerance. Agric. Salin. Assess. Manag. 2012, 2, $405-459$.

37. Mass, E. V Salt tolerance of plants. In CRC Handbook of Plant Science in Agriculture.; Christie, B.R., Ed.; CRC Press: Boca Raton, FL, USA, 2019; pp. 57-75.

38. Chen, T.W.; Kahlen, K.; Stützel, H. Disentangling the contributions of osmotic and ionic effects of salinity on stomatal, mesophyll, biochemical and light limitations to photosynthesis. Plant Cell Environ. 2015. [CrossRef] [PubMed]

39. Ben-Asher, J.; Garcia y Garcia, A.; Flitcroft, I.; Hoogenboom, G. Effect of atmospheric water vapor on photosynthesis, transpiration and canopy conductance: A case study in corn. Plant Soil Environ. 2013, 59, 549-555. [CrossRef]

40. Zhang, D.; Zhang, Z.; Li, J.; Chang, Y.; Du, Q.; Pan, T. Regulation of Vapor Pressure Deficit by Greenhouse Micro-Fog Systems Improved Growth and Productivity of Tomato via Enhancing Photosynthesis during Summer Season. PLoS ONE 2015, 10, e0133919. [CrossRef] [PubMed]

41. Miceli, A.; Gaglio, R.; Francesca, N.; Ciminata, A.; Moschetti, G.; Settanni, L. Evolution of shelf life parameters of ready-to-eat escarole (Cichorium endivia var. latifolium) subjected to different cutting operations. Sci. Hortic. 2019, 247, 175-183. [CrossRef]

42. Alfonzo, A.; Gaglio, R.; Miceli, A.; Francesca, N.; Di Gerlando, R.; Moschetti, G.; Settanni, L. Shelf life evaluation of fresh-cut red chicory subjected to different minimal processes. Food Microbiol. 2018, 73. [CrossRef]

43. Miceli, C.; Moncada, A.; Vetrano, F.; Iapichino, G.; D’Anna, F.; Miceli, A. Effect of Agronomic Practices on Yield and Quality of Borage at Harvest and During Storage as Minimally-Processed Produce. Agronomy 2020, 10, 242. [CrossRef]

44. European Union. Commission Regulation (EC) No. 1258/2011 of 2 December 2011 amending Regulation (EC) No. 1881/2006 as regards maximum levels for nitrates in foodstuffs. Off. J. Eur. Union 2011, 320, $15-17$.

45. Lillo, C.; Appenroth, K.-J. Light Regulation of Nitrate Reductase in Higher Plants: Which Photoreceptors are Involved? Plant Biol. 2001, 3, 455-465. [CrossRef]

46. Cova, A.M.W.; de Freitas, F.T.O.; Viana, P.C.; Rafael, M.R.S.; de Azevedo Neto, A.D.; Soares, T.M. Content of inorganic solutes in lettuce grown with brackish water in different hydroponic systems. Rev. Bras. Eng. Agrícola e Ambient. 2017, 21, 150-155. [CrossRef]

47. Pérez-López, U.; Miranda-Apodaca, J.; Lacuesta, M.; Mena-Petite, A.; Muñoz-Rueda, A. Growth and nutritional quality improvement in two differently pigmented lettuce cultivars grown under elevated CO2 and/or salinity. Sci. Hortic. 2015, 195, 56-66. [CrossRef]

48. Lee, S.K.; Kader, A.A. Preharvest and postharvest factors influencing vitamin C content of horticultural crops. Postharvest Biol. Technol. 2000, 20, 207-220. [CrossRef]

49. Stefanelli, D.; Goodwin, I.; Jones, R. Minimal nitrogen and water use in horticulture: Effects on quality and content of selected nutrients. Food Res. Int. 2010, 43, 1833-1843. [CrossRef]

50. Ruzzi, M.; Aroca, R. Plant growth-promoting rhizobacteria act as biostimulants in horticulture. Sci. Hortic. 2015, 196, 124-134. [CrossRef]

51. Aini, N.; Yamika, W.S.D.; Ulum, B. Effect of nutrient concentration, PGPR and AMF on plant growth, yield, and nutrient uptake of hydroponic lettuce. Int. J. Agric. Biol. 2019, 21, 175-183.

52. Balanza, V.; Martínez, J.A.; Conesa, E.; Egea-Gilabert, C.; Niñirola, D.; López-Marín, J.; González, A.; Fernández, J.A. Effect of PGPR application and nitrogen doses on baby leaf lettuce grown in a floating system. Acta Hortic. 2012, 952, 679-687. [CrossRef]

53. Woitke, M.; Hanafi, A.; Schnitzler, W.H. Effect of salinity and bacillus subtilis on white fly (Trialeurodes vaporariorum, Westwood) in hydroponically grown tomatoes (Lycopersicon esculentum Mill.). Acta Hortic. 2004, 659, 323-329. [CrossRef]

54. Dey, R.; Pal, K.K.; Bhatt, D.M.; Chauhan, S.M. Growth promotion and yield enhancement of peanut (Arachis hypogaea L.) by application of plant growth-promoting rhizobacteria. Microbiol. Res. 2004, 159, 371-394. [CrossRef]

55. Choudhary, D.K.; Sharma, K.P.; Gaur, R.K. Biotechnological perspectives of microbes in agro-ecosystems. Biotechnol. Lett. 2011, 33, 1905-1910. [CrossRef] 
56. Yuan, L.; Xu, D.-Q. Stimulation effect of gibberellic acid short-term treatment on leaf photosynthesis related to the increase in Rubisco content in broad bean and soybean. Photosynth. Res. 2001, 68, 39-47. [CrossRef]

57. Bhattacharyya, P.N.; Jha, D.K. Plant growth-promoting rhizobacteria (PGPR): Emergence in agriculture. World J. Microbiol. Biotechnol. 2012, 28, 1327-1350. [CrossRef]

58. Ahemad, M.; Kibret, M. Mechanisms and applications of plant growth promoting rhizobacteria: Current perspective. J. King Saud Univ. Sci. 2014, 26, 1-20. [CrossRef]

59. Kumar, A.; Prakash, A.; Johri, B.N. Bacillus as PGPR in Crop Ecosystem. In Bacteria in Agrobiology: Crop Ecosystems; Maheshwari, D., Ed.; Springer: Berlin/Heidelberg, Germany, 2011; pp. 37-59.

60. Richardson, A.E.; Barea, J.-M.; McNeill, A.M.; Prigent-Combaret, C. Acquisition of phosphorus and nitrogen in the rhizosphere and plant growth promotion by microorganisms. Plant Soil 2009, 321, 305-339. [CrossRef]

61. Whipps, J.M. Microbial interactions and biocontrol in the rhizosphere. J. Exp. Bot. 2001, 52, 487-511. [CrossRef] [PubMed]

62. Vetrano, F.; Miceli, C.; Angileri, V.; Frangipane, B.; Moncada, A.; Miceli, A. Effect of Bacterial Inoculum and Fertigation Management on Nursery and Field Production of Lettuce Plants. Agronomy 2020, 10, 1477. [CrossRef]

63. Moncada, A.; Vetrano, F.; Esposito, A.; Miceli, A. Fertigation management and growth-promoting treatments affect tomato transplant production and plant growth after transplant. Agronomy 2020, 10, 1504. [CrossRef]

64. Arkhipova, T.N.; Veselov, S.U.; Melentiev, A.I.; Martynenko, E.V.; Kudoyarova, G.R. Ability of bacterium Bacillus subtilis to produce cytokinins and to influence the growth and endogenous hormone content of lettuce plants. Plant Soil 2005, 272, 201-209. [CrossRef]

65. Dobbelaere, S.; Croonenborghs, A.; Thys, A.; Vande Broek, A.; Vanderleyden, J. Phytostimulatory effect of Azospirillum brasilense wild type and mutant strains altered in IAA production on wheat. Plant Soil 1999, 212, 155-164. [CrossRef]

66. Radhakrishnan, R.; Lee, I.-J. Gibberellins producing Bacillus methylotrophicus KE2 supports plant growth and enhances nutritional metabolites and food values of lettuce. Plant Physiol. Biochem. 2016, 109, 181-189. [CrossRef]

67. Chowdhury, S.P.; Dietel, K.; Rändler, M.; Schmid, M.; Junge, H.; Borriss, R.; Hartmann, A.; Grosch, R. Effects of Bacillus amyloliquefaciens FZB42 on lettuce growth and health under pathogen pressure and its impact on the rhizosphere bacterial community. PLOS ONE 2013, 8, e68818. [CrossRef]

68. Kanjanamaneesathian, M.; Wiwattanapatapee, R.; Rotniam, W.; Wongpetkhiew, W. Spraying hydroponic lettuce roots with a suspension concentrate formulation of Bacillus velezensis to suppress root rot disease and promote plant growth. N. Z. Plant Prot. 2014, 67, 213-219. [CrossRef]

69. Vurukonda, S.S.K.P.; Vardharajula, S.; Shrivastava, M.; SkZ, A. Enhancement of drought stress tolerance in crops by plant growth promoting rhizobacteria. Microbiol. Res. 2016, 184, 13-24. [CrossRef] [PubMed]

70. Egamberdieva, D. Survival of Pseudomonas extremorientalis TSAU20 and P. chlororaphis TSAU13 in the rhizosphere of common bean (Phaseolus vulgaris) under saline conditions. Plant Soil Environ. 2011, 57, 122-127. [CrossRef]

71. Shivakumar, S.; Bhaktavatchalu, S. Role of Plant Growth-Promoting Rhizobacteria (PGPR) in the Improvement of Vegetable Crop Production Under Stress Conditions. In Microbial Strategies for Vegetable Production; Zaidi, A., Khan, M.S., Eds.; Springer International Publishing: Cham, Switzerland, 2017; pp. 81-97. ISBN 978-3-319-54401-4.

72. Munns, R.; James, R.A.; Läuchli, A. Approaches to increasing the salt tolerance of wheat and other cereals. J. Exp. Bot. 2006, 57, 1025-1043. [CrossRef] [PubMed]

73. Kaushal, M.; Wani, S.P. Plant-growth-promoting rhizobacteria: Drought stress alleviators to ameliorate crop production in drylands. Ann. Microbiol. 2016, 66, 35-42. [CrossRef]

74. Jyothsna, P.; Murthy, S.D.S. A review on effect of senescence in plants and the role of phytohormones in delaying senescence. Int. J. Plant Anim. Environ. Sci. 2016, 6, 152-161.

75. Paul, D.; Lade, H. Plant-growth-promoting rhizobacteria to improve crop growth in saline soils: A review. Agron. Sustain. Dev. 2014, 34, 737-752. [CrossRef]

76. Vanderlinde, E.M.; Harrison, J.J.; Muszyński, A.; Carlson, R.W.; Turner, R.J.; Yost, C.K. Identification of a novel $\mathrm{ABC}$ transporter required for desiccation tolerance, and biofilm formation in Rhizobium leguminosarum bv. viciae 3841. FEMS Microbiol. Ecol. 2010. [CrossRef] 
77. Yang, J.; Kloepper, J.W.; Ryu, C.-M. Rhizosphere bacteria help plants tolerate abiotic stress. Trends Plant Sci. 2009, 14, 1-4. [CrossRef]

78. Downton, W.J.S.; Grant, W.J.R.; Robinson, S.P. Photosynthetic and stomatal responses of spinach leaves to salt stress. Plant Physiol. 1985, 78, 85-88. [CrossRef]

79. Pierik, R.; Tholen, D.; Poorter, H.; Visser, E.J.W.; Voesenek, L.A.C.J. The Janus face of ethylene: Growth inhibition and stimulation. Trends Plant Sci. 2006, 11, 176-183. [CrossRef]

80. Zafar-ul-Hye, M.; Danish, S.; Abbas, M.; Ahmad, M.; Munir, T.M. ACC deaminase producing PGPR Bacillus amyloliquefaciens and Agrobacterium fabrum along with biochar improve wheat productivity under drought stress. Agronomy 2019, 9, 343. [CrossRef]

81. Saleem, A.R.; Brunetti, C.; Khalid, A.; Della Rocca, G.; Raio, A.; Emiliani, G.; De Carlo, A.; Mahmood, T.; Centritto, M. Drought response of Mucuna pruriens (L.) DC. inoculated with ACC deaminase and IAA producing rhizobacteria. PLoS ONE 2018, 13, e0191218. [CrossRef] [PubMed]

82. Glick, B.R. Bacteria with ACC deaminase can promote plant growth and help to feed the world. Microbiol. Res. 2014, 169, 30-39. [CrossRef] [PubMed]

83. Bharti, N.; Barnawal, D. Chapter Five-Amelioration of Salinity Stress by PGPR: ACC Deaminase and ROS Scavenging Enzymes Activity. In PGPR Amelioration in Sustainable Agriculture; Singh, P.K., Kumar, A., Singh, A.K., Eds.; Woodhead Publishing: Sawston, UK, 2019; pp. 85-106. ISBN 978-0-12-815879-1.

84. Miceli, A.; Moncada, A.; D'Anna, F. Effect of water salinity on seeds-germination of Ocimum basilicum L., Eruca sativa L. and Petroselinum hortense Hoffm. Acta Hortic. 2003, 609, 365-370. [CrossRef]

85. D'Anna, F.; Incalcaterra, G.; Moncada, A.; Miceli, A. Effects of different electrical conductivity levels on strawberry grown in soilless culture. Acta Hortic. 2003, 609, 355-360. [CrossRef]

86. Arora, N.K.; Tewari, S.; Singh, S.; Lal, N.; Maheshwari, D.K. PGPR for Protection of Plant Health Under Saline Conditions. In Bacteria in Agrobiology: Stress Management; Maheshwari, D.K., Ed.; Springer: Berlin/Heidelberg, Germany, 2012; pp. 239-258. ISBN 978-3-642-23465-1.

(C) 2020 by the authors. Licensee MDPI, Basel, Switzerland. This article is an open access article distributed under the terms and conditions of the Creative Commons Attribution (CC BY) license (http://creativecommons.org/licenses/by/4.0/). 